\title{
The Diest Formation: a review of insights from the last decades
}

\author{
Rik HOUTHUYS ${ }^{*}$, Rieko ADRIAENS², Stijn GOOLAERTS ${ }^{3}$, Piet LAGA, Stephen LOUWYE 5 , Johan MATTHIJS 6 , \\ NOËL VANDENBERGHE ${ }^{7}$ \& JASPER VERHAEGEN ${ }^{8}$
}

${ }^{1}$ Geoconsultant, Halle, Belgium; rik.houthuys@telenet.be.

${ }^{2}$ Qmineral, Heverlee-Leuven, Belgium; radriaens@qmineral.com.

${ }^{3}$ OD Earth \& History of Life and Scientific Heritage Service, Royal Belgian Institute of Natural Sciences, Vautierstaat 29, B-1000 Brussels, Belgium; stijn.goolaerts@naturalsciences.be.

${ }^{4}$ Geological Survey of Belgium, Brussels, Belgium; piet.laga@skynet.be.

${ }^{5}$ Geology, UGent, Belgium; stephen.louwye@ugent.be.

6VITO, Mol,Belgium; johan.matthijs@vito.be.

${ }^{7}$ Dept. Earth and Environmental Sciences, KU Leuven, Belgium; noel.vandenberghe@kuleuven.be.

${ }^{8}$ VPO, Planning Bureau for the Environment and Spatial Development, Department of Environment, Flemish Government, Koning Albert II-laan 20, 1000 Brussels, Belgium; jasper.verhaegen@vlaanderen.be.

${ }^{*}$ corresponding author.

ABSTRACT. Research conducted since the 1960s on the upper Miocene Diest Formation in NE Belgium is reviewed and integrated. Their lithology unites the deposits of the glauconiferous Diest Sand in one formation, though biozones and internal sedimentary structures strongly suggest the formation may agglomerate the deposits of two separate, successive sedimentary cycles.

The lowermost cycle is thought to have deposited the "Hageland Diest sand" during the early or middle Tortonian. It contains the Diest Sand in the main outcrop area in Hageland, Zuiderkempen and central Limburg, and probably also the Deurne Member near the city of Antwerpen. It furthermore includes the lower part of the Dessel Member in the central Kempen and in the Belgian part of the Roer Valley Graben (RVG). The Hageland Diest cycle represents the infill of a large tidal inlet tributary to the southern North Sea bight, then situated over the southern Netherlands and the Lower Rhine embayment. The Hageland Diest sand has the composition of a marine deposit, yet the confined area of occurrence and the presence of tens of metres deep incisions at the base, set it apart. The confinement of the embayment, strong tides and a steady supply of coastal-marine sand are invoked as the main driving forces that resulted in the distinctive geometry and internal architecture of the unit.

The upper cycle is associated with the "Kempen Diest sand", which is found in the subsurface of the RVG and the Noorderkempen. It has a late Tortonian to earliest Messinian age with progressively younger ages occurring to the NW. It encompasses the upper part of the Dessel Member and the overlying, coarser Diest Sand, and correlates to most or all of the thickly developed Diessen Formation in The Netherlands. It is the deposit of a prograding marine delta, containing both marine components and continental components fed by the palaeo-Meuse/Rhine river mouths. Accommodation space kept increasing during deposition, due to subsidence of the deposition area, especially inside the RVG but also in the Noorderkempen.

Although there is a fair consensus on the above, many concrete points about the geometry and depositional history of the Diest Formation and even a definitive decision on its single or dual character remain to be sorted out.

In addition, this review excludes the Flemish Hills sand and the Gruitrode Member from the Diest Formation.

KEYWORDS: Upper Miocene, Tortonian, confined embayment, deltaic progradation, depositional model, lithologic provenance, glauconiferous quartz sand.

\section{Introduction and aim of this review}

The Diest Formation is an important Neogene deposit in NE Belgium (Fig. 1a). It consists of greyish-green to brownish-green, fine to coarse grained, locally clayey, glauconiferous sand. In outcrop in the Hageland and Zuiderkempen areas (Fig. 1a, b), the sand is locally iron-cemented. The formation constitutes the interior of the longitudinal, parallel Hageland Hills around Leuven and Diest (Gullentops, 1957; Houthuys \& Matthijs, 2018). More to the north, in the Kempen (Campine) subsurface, it is found as a tens of metres thick sand deposit that hosts an important aquifer. The main lithological composition and appearance in both regions are similar, though certain aspects of their lithology and style and time of deposition are different (Vandenberghe et al., 2014). Below the Hageland outcrop area and its NE subsurface extension, an important incised depression is present at the base of the Diest Formation. To the west, some outliers on the Flemish hills, a long row of hills near the Flanders-Wallonia boundary, from Flobecq to Cassel in northern France (Fig. 1a), were traditionally assigned to the Diest Formation although doubt about this designation has always existed (review in Houthuys, 2014).

Scientific contributions of the past sixty years addressed the precise age of deposition, the internal variation, the depositional conditions, the extent and the relationship to outliers. They significantly adjusted the views held by the 1960s. This article summarizes and integrates the contributions and describes the present-day views of the Diest Formation. Hyperlinks throughout this text refer to the Flemish Authorities' borehole and outcrop database "DOV" (Databank Ondergrond Vlaanderen) that holds locations, descriptions, interpretations, logs etc. (Table 1) (De Nil et al., 2020, this volume).

\section{History and definition of the Diest Formation}

The Diest Formation has been recognized as a lithostratigraphic unit in the earliest geological publications. The name "Diestien", after the town of Diest in the NE corner of the province of Vlaams-Brabant (Fig. 1b), was formally introduced by Dumont (1839). He divided the Belgian Cenozoic rocks into six systems, one of which was the "système Diestien". It included "sable glauconifère, sable ferrugineux et grès ferrugineux" occurring in the Hageland type area. It can be inferred from Dumont (1849) that he included the relatively coarse glauconiferous sand in the Kempen subsurface in this unit. Though trace fossils are abundant, the sand is mostly devoid of macrofossils, especially in the outcrop area (De Meuter \& Laga, 1976). This fact is at the origin of some controversies about lateral correlations with outliers. At a small number of locations (Pellenberg, Bolderberg), silicified, reworked Bolderberg Formation fossils, as well as a mixture of Diest and Bolderberg Formation faunas, have been found in the base gravel (Tavernier \& de Heinzelin, 1962). However, in a small area near Antwerpen, macroscopic calcareous fossils do occur in abundance in the local member called Deurne Sand (Figs 2 and 3, De Meuter \& Laga, 1976); and in the Kempen subsurface, calcareous and organic walled microfossils are locally well preserved in the Dessel Member.

The Diest Formation was first included in the Pliocene series (1896 and 1929 geological maps) and later in the upper Miocene (de Heinzelin, 1955; Glibert \& de Heinzelin, 1955a,b). Foraminiferal biostratigraphical studies by De Meuter \& Laga (1970), Hooyberghs \& De Meuter (1972) and Laga \& De Meuter (1972) led to the formal definition of the upper Miocene Diest Formation (De Meuter \& Laga, 1976).

The bulk of the deposits constituting the Diest Formation are 


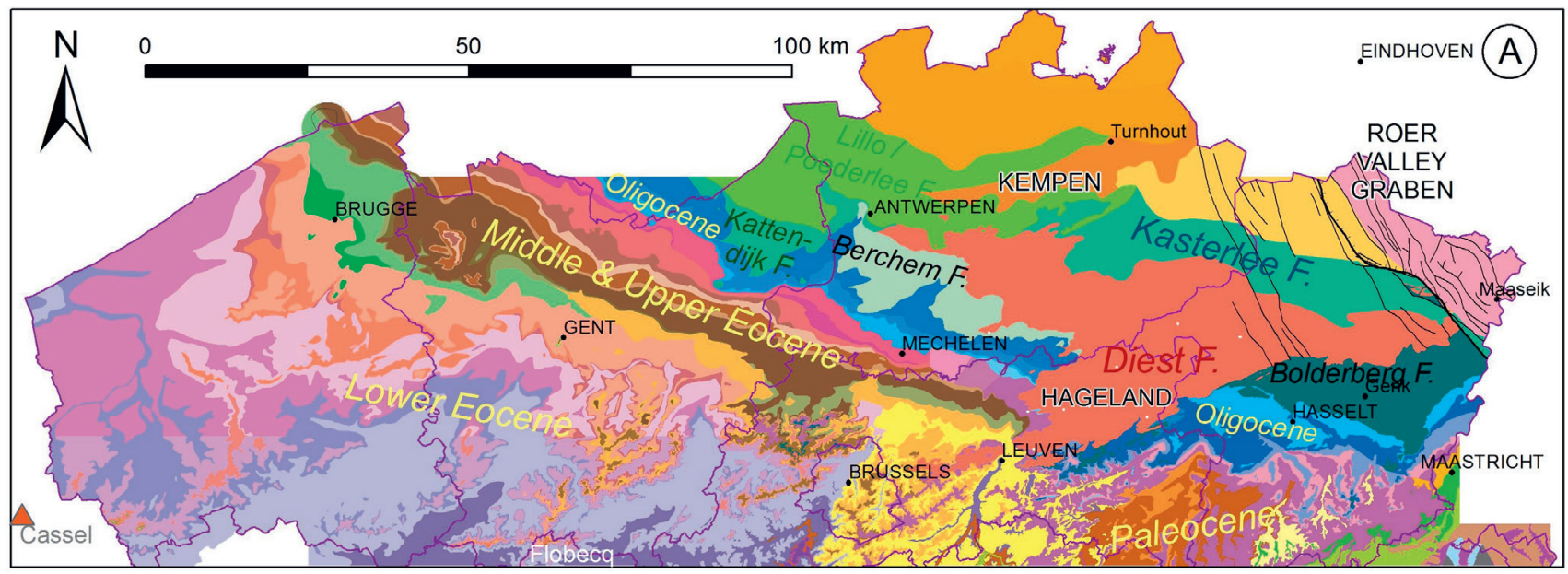

Figure 1. Location and outcrop maps. a) Outcrop map of Northern Belgium (DOV, 2019). Thin Quaternary cover and locally thick Quaternary marginal marine, estuarine and fluvial sediments have been stripped. The outcrop area of the Diest Formation (F.) and the underlying Berchem F. and Bolderberg F. as well as the overlying Kasterlee F. + Kattendijk F. and Lillo F. + Poederlee F. has been labelled. Faults affecting the Diest F. have been added. b) Diest F. outcrop and subcrop area (subcrop covered by Kasterlee F.) in NE Belgium. Formation contours from G3Dv3 (Deckers et al., 2019). Location names cited in the text.

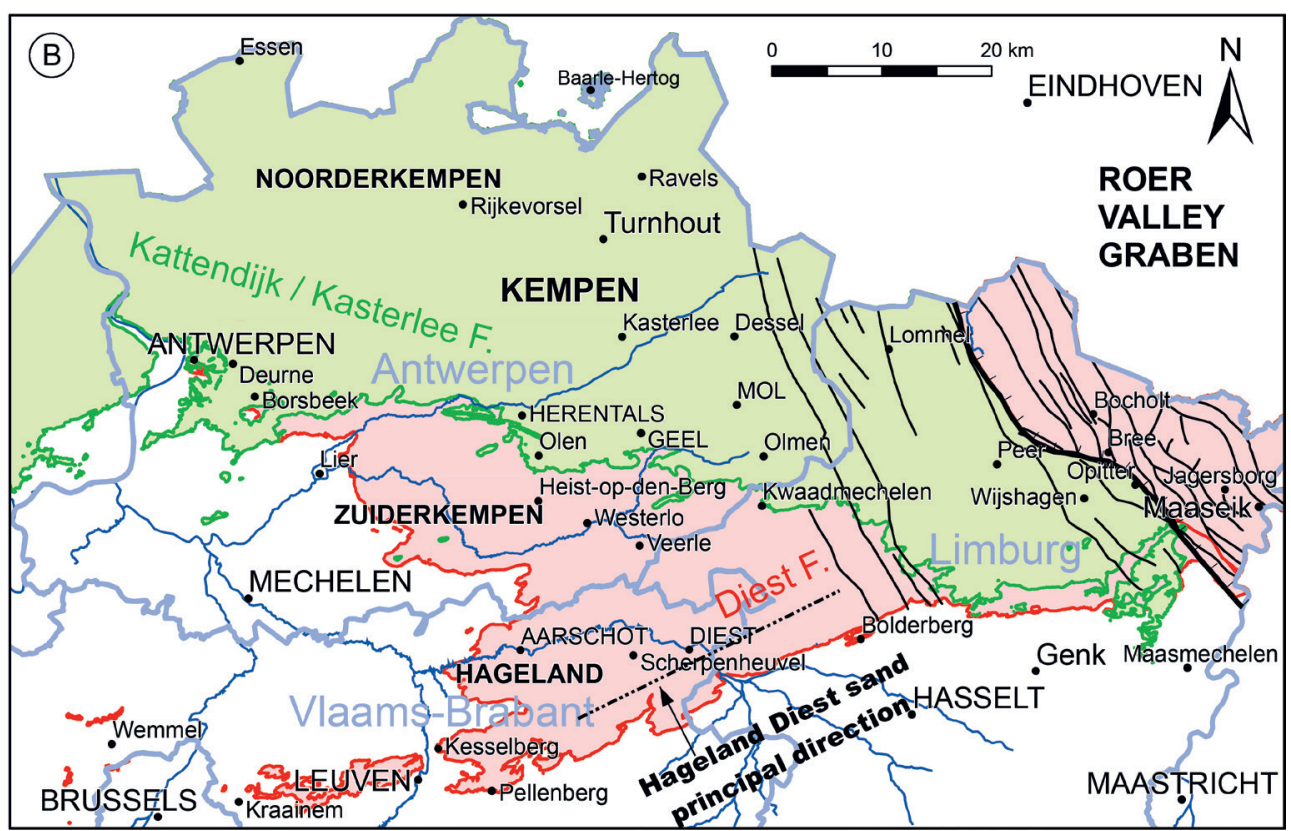

informally called the "Diest sand". Near the base of the Diest Formation, two medium-fine to fine-grained sandy members have locally been distinguished: the Deurne Member and Dessel Member (Fig. 3). In contrast to the bulk of the formation, these sub-units do contain calcareous fossils at many locations.

Glibert \& de Heinzelin (1955a,b) described the Deurne Sand sub-unit. It contains many calcareous macrofossils, was formerly named "sables à Terebratula perforata" by Nyst (1861), and it only occurs just east and NE of the city of Antwerpen. The unit consists of grey-green, medium-fine, very slightly clayey, glauconiferous sand, locally very rich in nests of Bryozoa, Brachiopoda and Ditrupa, with white, glauconite-rimmed trace fossils, and a base gravel with small rounded flint pebbles, bone fragments and shark teeth. The presence of internal clasts of Terebratula brachiopods in the limonitic sandstones of the Diest Sand in the Hageland and Kempen regions allowed correlating the Diest Sand and Deurne Sand (Laga \& Louwye, 2006). Another sub-unit, the Dessel Sand, was identified in cored wells at Dessel (Laga \& De Meuter, 1972) as the lower, finegrained glauconiferous sand, containing foraminifera and organicwalled microfossils, of the same Diest Formation. The Dessel Sand appears to occur throughout most of the Kempen area, as the lower part near the base of the Diest Formation, and was called "sables fins du Diestien" by Gulinck et al. (1963).

The first geological maps of Belgium $(1896,1929)$ considered another glauconiferous sand unit, the "Kasterlee Sand" and its (quasi) lateral equivalent, the "Kattendijk Sand" (then known as "sables à Isocardia cor"), as part of the Diest Formation. They were often referred to as the "Diestien supérieur". They were considered as the regressive facies of the Diestien (Tavernier \& de Heinzelin, 1962). In some outcrops, the Kasterlee Sand unit contains reworked Diest Sand near its base (Fobe, 1995;
Verhaegen et al., 2014). Kasterlee Sand and Kattendijk Sand were later shown to represent two successive marine (or marginal marine) sedimentary deposits postdating the Diest Formation: the uppermost Miocene Kasterlee Formation (Louwye et al., 2007; Vandenberghe et al., 2020, this volume), and the lower Pliocene Kattendijk Formation (Louwye et al., 2007).

\section{Extent, correlatives and age of the Diest Formation}

The Diest Formation forms a depositional unit of varying thickness in the provinces of Vlaams-Brabant, Antwerpen and in the northern part of Limburg (Fig. 1b). In the NE, the thickness of the formation may reach up to 200 metres inside the Roer Valley Graben (RVG). The thickness decreases to the SW. Defying this general trend, in Hageland and Zuiderkempen, important thickness variations are related to incisions at the base. To the north, the formation is covered by younger Neogene deposits (Fig. 1b). In most of its occurrence area the Diest Formation is overlain by the Kasterlee Formation (Vandenberghe et al., 2020, this volume).

The Diest Formation is a marine deposit connected to the southern North Sea Basin, and more particularly to the embayment that during the Miocene occupied the Lower Rhine Graben. In this paper, the term "open sea" refers to this embayment as well as the North Sea towards the north. In and west of the Hageland area, the Diest Formation reaches further inland with respect to the occurrence of the older, underlying Oligocene and Neogene deposits (Fig. 1a). Here it fills a confined and incised basin whose long axis crosses at an angle the strikes of the older strata. This axis is directed WSW-ENE (about N60 E; Fig. 1b), and as it turns up repeatedly in relation with the Hageland Diest sand, it is named its "principal direction" in this article. 
Table 1. List of boreholes referred to in this publication. Location: https://www.dov.vlaanderen.be/data/opdracht/2020-021774.

\begin{tabular}{|c|c|c|c|c|c|}
\hline $\begin{array}{l}\text { Name used in this } \\
\text { publication }\end{array}$ & GSB code & $\begin{array}{l}\text { DOV code }+ \\
\text { link to database }\end{array}$ & $\begin{array}{l}\text { Name used in this } \\
\text { publication }\end{array}$ & GSB code & $\begin{array}{l}\text { DOV code }+ \\
\text { link to database }\end{array}$ \\
\hline Beerse URS & 017W0354 & $2022-167$ & ON-Dessel-5 & 031W0370 & ON-Dessel-5 \\
\hline Gasthuisberg & - & VLA17-4.1-001-TO1 & Opitter seismometer & 048E0294 & BGD048e0294 \\
\hline Geel & 046W0388 & $\mathrm{B} / 1-1100$ & Pidpa Oostmalle & 029E0249 & $\mathrm{kb} 16 \mathrm{~d} 29 \mathrm{e}-\mathrm{B} 276$ \\
\hline Herselt & 060Е0289 & $\mathrm{B} / 1-1115 \mathrm{a}$ & Pidpa Poederlee & 030W0300 & kb16d30w-B315 \\
\hline Hoogstraten & $007 \mathrm{E} 0206$ & kb8d7e-B47 & Pidpa Retie & 031W0243 & $\mathrm{kb} 17 \mathrm{~d} 31 \mathrm{w}-\mathrm{B} 228$ \\
\hline Lommel & 032W0409 & kb17d32w-B379 & Rees & 017E0399 & kb8d17e-B495 \\
\hline Maaseik /Jagersborg & 049W0220 & kb18d49w-B220 & Rijkevorsel & $016 \mathrm{E} 0153$ & kb8d16e-B37 \\
\hline Mol Belchim & 031w0221 & kb17d31w-B212 & Scherpenheuvel & $075 \mathrm{E} 0340$ & kb24d75e-B344 \\
\hline Mol peilput & 031w0237 & $\mathrm{B} / 1-0158$ & Veerle & 060E0215A & kb24d60e-B219 \\
\hline Neeroeteren & 064W0234 & kb26d64w-B242 & Weelde & 008E0133 & kb8d8e-B26 \\
\hline ON Mol 2 & 031E0440 & ON-Mol-2B & Wijshagen & 048W0180 & kb18d48w-B181 \\
\hline ON-Dessel-2 & 031W0338 & kb17d31w-B299 & Zichem & 076W0329 & BGD076w0329 \\
\hline
\end{tabular}

\begin{tabular}{|c|c|c|c|c|c|c|c|}
\hline $\begin{array}{l}\text { Currently used } \\
\text { older names }\end{array}$ & Ge & $\begin{array}{l}\text { EGEND } \\
\text { ogical Map } \\
\text { 1896) } \\
\text { tages" }\end{array}$ & Ge & $\begin{array}{l}\text { LEGEND } \\
\text { ological Map } \\
\text { (1929) } \\
\text { "Stages" }\end{array}$ & \multicolumn{3}{|c|}{$\begin{array}{c}\text { STRATIGRAPHICAL TABLE } \\
\text { de Heinzelin, } 1955 \\
\text { Tavernier \& de Heinzelin, } 1962\end{array}$} \\
\hline $\begin{array}{l}\text { 'Sables à Fusus (Chrysodomus) } \\
\text { contrarius (or Neptunea c.)' } \\
\text { 'Falun blanchâtre' }\end{array}$ & \multirow{3}{*}{$\begin{array}{l}\underset{\mathrm{U}}{\mathrm{U}} \\
\frac{\mathrm{O}}{\mathrm{a}}\end{array}$} & Scaldisien & \multirow[b]{3}{*}{ 觅 } & Scaldisien & 岂 & Scaldisien & $\begin{array}{l}\text { Sables de Kallo } \\
\text { Sables de Luchtbal }\end{array}$ \\
\hline $\begin{array}{l}\text { 'Sable gris glauconifère à Iso- } \\
\text { cardia cor' or 'Sable à Ditrupa' }\end{array}$ & & \multirow[b]{2}{*}{ Diestien } & & \multirow[b]{2}{*}{ Diestien } & $\frac{0}{a}$ & & Sables de Kattendijk \\
\hline $\begin{array}{l}\text { 'Sables et grès de Diest } \\
\text { à Terebratula perforata' } \\
\text { or 'Sable à Hétérocètes' }\end{array}$ & & & & & 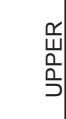 & \multirow[t]{2}{*}{$\begin{array}{l}\text { Deurnien } \\
\text { (= Diestien) }\end{array}$} & $\begin{array}{l}\text { Sables de Diest } \\
\text { Sables de Deurne }\end{array}$ \\
\hline $\begin{array}{l}\text { 'Sable noir d'Anvers à } \\
\text { Pectunculus pilosus' }\end{array}$ & \multirow{3}{*}{ 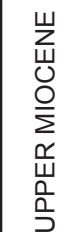 } & \multirow{3}{*}{ Bolderien } & \multirow{3}{*}{ 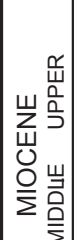 } & \multirow{3}{*}{$\begin{array}{l}\text { Anversien } \\
\text { (= Antwerpiaan) } \\
---- \\
\text { Bolderien }\end{array}$} & \multirow{3}{*}{ 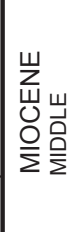 } & & \\
\hline $\begin{array}{l}\text { 'Sable argileux d'Edeghem à } \\
\text { Panopea menardi' }\end{array}$ & & & & & & Anversien & $\begin{array}{l}\text { Sables d'Anvers } \\
\text { Sables d'Edegem }\end{array}$ \\
\hline & & & & & & Houthalenien & Sables d'Houthalen \\
\hline
\end{tabular}

Figure 2. Formerly used stratigraphic names, after De Meuter \& Laga (1976, table 1, p. 140).

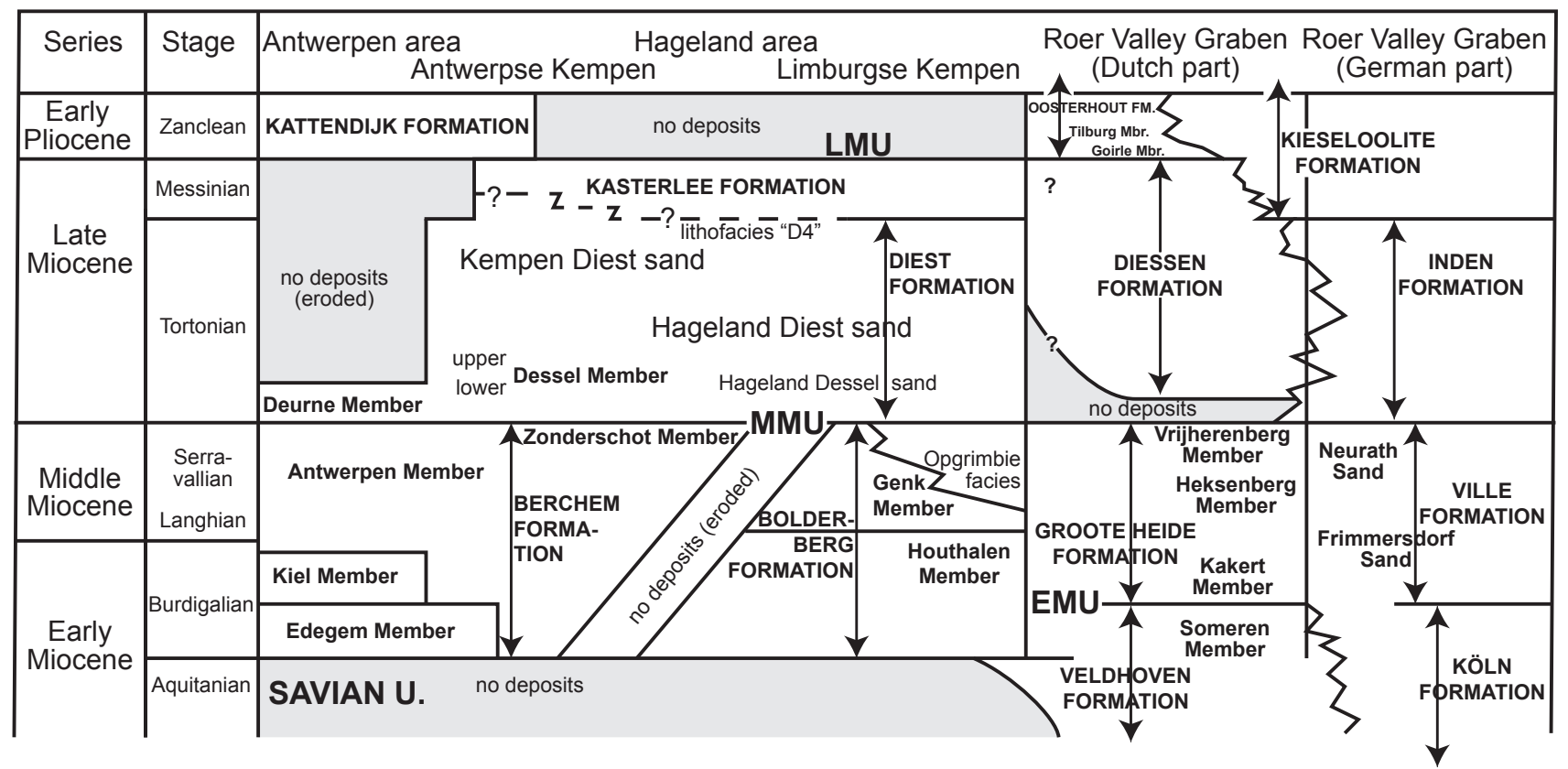

Figure 3. Present-day lithostratigraphic names in their geographic context. Based on Vandenberghe et al. (2014, table 1) and Munsterman et al. (2020, fig. 8), with Hageland and Kempen Diest sand defined in this publication added. Existing formal names are in bold. EMU = Early Miocene Unconformity; $\mathrm{MMU}=$ Mid Miocene Unconformity; LMU = Late Miocene Unconformity. 
The Diest Formation extends northward into the subsurface of the Kempen and the neighbouring area in The Netherlands. A small isolated remnant of the Diest Formation occurs just NW of Brussels. Another series of outliers constitute an up to $25 \mathrm{~m}$ thick unit found in the Flemish Hills, between Pottelberg (Flobecq) in the east and Cassel (N. France) in the west (Fig. 1a) although the stratigraphic position of this unit as part of the Diest Formation is disputed (Houthuys, 2014).

The Diest Formation was deposited during the late Miocene Tortonian (11.6-7.2 Ma) and earliest Messinian (7.2-5.3 Ma) (Louwye et al., 1999; Louwye \& Laga, 2008). Organic walled microfossils could only be retrieved in the north and NE of the area of its occurrence. There, an overall progradation from SE to NW could be established, based on micropalaeontology (Louwye et al., 1999; Vandenberghe et al., 2014; King, 2016; Deckers \& Louwye, 2020).

In the subsurface of The Netherlands, the Diest Formation is included in the (former) Breda Formation, the latter containing all glauconiferous sand, clayey sand and clay deposited in The Netherlands during the Miocene (Van Adrichem Boogaert \& Kouwe, 1993-1997). The Diest Formation is chiefly part of the Tortonian and thus correlates only to the upper part of the Breda Formation. The Belgian-Dutch joint project "H3O - De Kempen" (Vernes et al., 2018, p. 183) modelled the "extended Diest Formation" as the Belgian Diest Formation which was correlated to the sandy, prograding middle and upper units of the Breda Formation, such as expressed in seismic lines, and defined at the base by the Mid Miocene Unconformity (MMU). The base of the extended Diest Formation was identified as a well traceable, strong impedance contrast.

Using lithological characteristics, large-scale depositional architecture revealed by seismic profiles and new biostratigraphic analyses, Munsterman et al. (2020) proposed to redefine the deposits of the Breda Formation. In this revision, the upper part of the Breda Formation that correlates to the Belgian Diest Formation is singled out as the new Diessen Formation (Munsterman et al., 2020). The Diessen Formation attains a maximum thickness of $500 \mathrm{~m}$ in the centre of the RVG in an area about $20 \mathrm{~km}$ north of Eindhoven. It thins towards the SW to $220 \mathrm{~m}$ inside the RVG and $125 \mathrm{~m}$ outside the RVG. The Diessen Formation is bounded below by a surface identified as the MMU. It is expressed as a depositional hiatus surface at least spanning the earliest Tortonian. The top surface is an erosional truncation correlated to the Late Miocene Unconformity (LMU), and can be dated in the area at the Miocene to Pliocene transition. The correlation scheme in Munsterman et al. (2020) does not mention the Belgian Kasterlee Formation, but when biostratigraphic data are taken into account (Vandenberghe et al., 2020, this volume), its correlative deposits must be included in the Diessen Formation.

\section{Lithology}

Especially in the south and SE part of its extent the base of the formation often shows a gravel of rounded flint pebbles, usually without fossils. At locations where erosional incisions characterize the base of the Diest Formation, the pebbles are reworked from older deposits. In case fossils do occur in the basal gravel, they are a product of reworking. At the southern edge of the outcrops of Kesselberg near Leuven, two thin pebble layers are found inserted in the formation a few metres above its pebbly base. This demonstrates the close link between incision, erosion of older strata and incorporation of reworked elements in the lower part of the Diest Formation. A well-developed base gravel is also found near the city of Antwerpen; it is often rich in fossils. A basal gravel and/or a level with coarse quartz grains has also been reported in the Antwerpen Province (Louwye et al., 2007; Vandenberghe et al., 2014). It becomes more discontinuous going northward and eventually disappears.

The Diest Formation is dominated by poorly sorted, very glauconiferous quartz sands. Sometimes the formation is slightly clayey, locally with thick mud drapes or layered bundles of thin mud drapes associated with the bottomset part of large-scale crossbeds. The median and modal grain size is mostly above $250-300$ $\mu \mathrm{m}$ and locally approaches $500 \mu \mathrm{m}$ (Gullentops, 1963; Wouters \& Schiltz, 2012; Adriaens, 2015; Verhaegen, 2020, this volume). In its lower part, especially in the Kempen, finer grain sizes between 150 and $200 \mu \mathrm{m}$ are found. Moderate to poor sorting is characteristic for the Diest Formation. Finer and coarser fractions are often represented in about equal amounts. Many samples contain a subpopulation of coarse, 0.5 to $2 \mathrm{~mm}$, subangular or angular quartz grains. This fraction may also contain fragments of flint and other rocks. Cored samples are difficult to retrieve from the loose medium to coarse sand. The vertical grain-size profile is either (in the case of medium to coarse sand) stable, or shows a coarsening upwards trend. Secondary cyclic grain-size variations often characterize the profile. A comprehensive overview of the spatial and vertical grain-size variations throughout the area of the Diest Formation is still lacking.

The Diest Formation is highly glauconiferous: on average, glauconite pellets constitute between 35 and $40 \%$ of the total mass. Locally, values up to 50 and $60 \%$ are not exceptional. Lower glauconite values of about $25 \%$ occur in the Dessel Member (Vandenberghe et al., 2014). Glauconite pellets are slightly finer sized than the quartz grains in the same sample, indicating, as they are also slightly heavier, that they have been transported along with the quartz grains. The age determined using $\mathrm{K} / \mathrm{Ar}$ dating on glauconite grains is systematically older than the age determined using micropalaeontology (Vandenberghe et al., 2014). This supports the observation that glauconite pellets in the Diest Formation are reworked.

Samples from the Diest Formation taken in medium to coarse sand may contain a minor clay fraction. It consists mostly of interstratified glauconite/smectite and represents an abrasion or disintegration product of the pelletal glauconite (Adriaens et al., 2014; Adriaens \& Vandenberghe, 2020, this volume). Clay can also be present in mud drapes, or, where the deposit consists of fine sand, as dispersed clay. This is mostly detrital clay with a high smectite content (Adriaens \& Vandenberghe, 2020, this volume).

The heavy mineral assemblage of the Diest Formation shows mixing of a northern, marine dominated provenance (epidote, amphiboles and garnet) and a southern, continental provenance (tourmaline, staurolite, kyanite and andalusite) (Verhaegen et al., 2019). A mostly northern marine provenance can be observed in the area near Antwerpen and in the basal Dessel Member. Most of the Kempen Basin shows a mixed signal but in the south and SE, near the RVG, a strong southern continental provenance can be deduced (Verhaegen et al., 2019; Verhaegen, 2020, this volume). The ratio andalusite/kyanite is highest in the Flemish Hills, and gets progressively lower for the Hageland, Limburgse Kempen, Antwerpse Kempen and finally Antwerpen area. This ratio appears to be a good provenance indicator whereby the increased presence of andalusite can be linked to a southern provenance and associated with reworking of Eocene sediments from Flanders, the Ardennes and/or the Paris Basin.

Due to the relatively elevated topographic position of many Diest Formation outcrops in Hageland and Zuiderkempen, quartz grains often have a limonite coating and glauconite pellets are partly oxidized and altered at the surface. Heavy mineral samples taken from outcrops in the Hageland hills or from shallow subcrops in the Limburgse Kempen area show compositional shifts towards weathered assemblages, which is diagnosed by the disappearance of garnet and an increase in ultra-stable components (Verhaegen et al., 2019). The outcrops are also completely devoid of calcium carbonates. Siderite (iron carbonate) is found (Laga, 1972; Adriaens 2015), as well as rare steinkerns. They demonstrate that the entire formation originally contained carbonate particles and fossil remains, such as are still found in many drillings in the Kempen subcrop area, especially in the Dessel Member in the lower part of the formation (Adriaens, 2015). The original carbonate content was probably not very high, as sedimentary and biogenic structures are often well preserved, which would not be the case if strong decalcification had taken place. In all outcrops, especially in Hageland, where parts of the formation are situated above the (palaeo)groundwater tables, either irregular or more or less planar zones are loosely to strongly cemented by iron hydroxides and oxides. They yielded local building stones, the well-known Hageland iron sandstone (Bos \& Gullentops, 1990; Dreesen et al., 2010; De Clercq et al., 2014). They can only have formed after emersion, in oxygenated conditions, and when an initial relief was installed. In the outcrop area, thick ironstones are found primarily near the sides of hills, not in their core (Houthuys \& Matthijs, 2018). 


\section{The basal surface of the Diest Formation}

The basal surface of the Diest Formation is relatively well known from outcrop and numerous boreholes. These are mostly flush borings, but even in those lacking dense sampling or continuous borehole logging, the base is easily recognized as a change in grain size and glauconite content, also accompanied by a change in relative firmness of the deposits. Most formation interfaces in the Belgian Neogene are fairly regular and smooth and form more or less parallel surfaces. The base of the Diest Formation is however a complex and highly erosive surface. Erosion preceded the deposition of the Diest Formation everywhere outside the RVG as variable thicknesses of the underlying Berchem and Bolderberg Formations have been removed (Vandenberghe et al., 2014). Tens of metres-deep incised depressions in western Hageland are observed in outcrop, around Leuven and Aarschot. Borehole and seismic survey evidence (De Batist \& Versteeg, 1998) shows similar-sized depressions are also present in east Hageland and the neighbouring Zuiderkempen area.

The map of the basal surface shown in Vandenberghe et al. (2014, fig. 2) was that of the G3D version 2 model (Matthijs et al., 2013). G3D version 3 (Deckers et al., 2019) (Fig. 4) maintained the structure of version 2 for the incised area of Hageland and the Zuiderkempen. It was constructed with the underlying assumption that the deepest points reflect a drowned river valley system (Timothy Lanckacker, pers. comm., in Houthuys, 2014). In the Antwerpse Kempen, new insights from geophysical borehole logs resulted in a smoother basal surface where many of the small channels modelled in version 2 are now no longer present. This implies a smaller amount of incisions in the Berchem Formation (Deckers et al, 2019).

However, the valleys connecting the deepest points are positioned in areas without boreholes and are thus not directly supported by data. An alternative interpretation presented in Figure 5 considers the deeper points to be situated in enclosed basal troughs. The idea of enclosed elongate depressions has earlier been applied in the map published by Houbolt (1982, fig. 7) which was based on data of the Hageland area compiled by Van Calster (1960). The closed trough model is locally supported by seismic surveys, though a definitive choice for a "valley" or "closed trough" model for the basal surface awaits new evidence from well-located boreholes or geophysical surveys.

The basal surface of the combined Berchem/Bolderberg Formation can be consulted on DOV (2020). In the Antwerpse Kempen, it shows a uniform $0.45 \%$ slope dipping to $\mathrm{N} 35^{\circ} \mathrm{E}$. More to the south, between Brussels and Heist-op-den-Berg, the general, averaged slope is smaller: about $0.2 \%$.
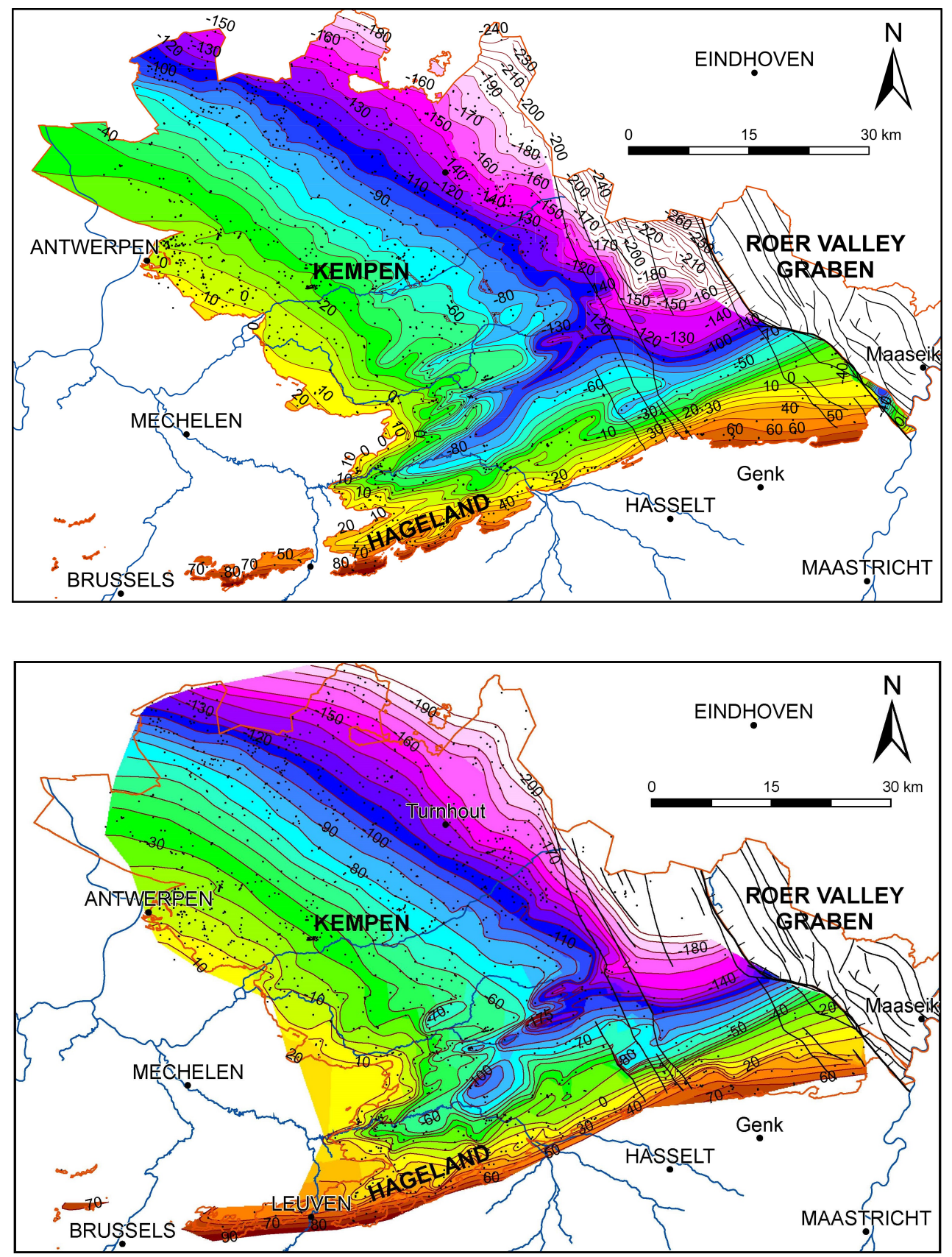

Figure 4. Basal surface of the Diest Formation (coloured surface; elevation range from $-200 \mathrm{~m}$ in $\mathrm{NE}$ to $+90 \mathrm{~m}$ in SW) like modelled in G3Dv3 (Deckers et al., 2019) (see contour lines, $10 \mathrm{~m}$-interval). Black dots are boreholes where the base was found.

Figure 5. Basal surface of the Diest Formation (coloured surface; elevation range from $-200 \mathrm{~m}$ in $\mathrm{NE}$ to $+90 \mathrm{~m}$ in SW) based on manual interpolation (see contour lines, $10 \mathrm{~m}$-interval) of base elevation in boreholes (dots). Source of data: G3Dv2 (Matthijs et al., 2013); seismic surveys (De Batist \& Versteeg, 1998; Jef Deckers, pers. comm., 2019). 
North of the major incised zone, and also to the SW between Brussels and Heist-op-den-Berg, the basal surface of the Diest Formation displays the same slope values and strikes as the base of the Bolderberg/Berchem Formation. Both formations are therefore parallel, but nevertheless, the contact is an unconformity, also in the part of the Diest basin where no major incisions are found at the base, as a depositional hiatus is present between the top of the Berchem Formation (Langhian, 16.0-13.8 Ma) and the base of the Diest Formation (Tortonian, 11.6-7.2 Ma) (Louwye et al., 2007; Vandenberghe et al., 2014).

At about the same Serravallian (13.8-11.6 Ma) age, a major depositional hiatus is found in the UK, Danish, German and Dutch sectors of the North Sea (Wong et al., 2007; Rasmussen \& Dybkjær, 2014) related to an important regional event, called the Mid Miocene Unconformity (MMU). It has been associated with tectonic basin subsidence in the North Sea (Rasmussen \& Dybkjær, 2014) and with regional vertical tectonic rearrangement in the southern North Sea Basin area (Vandenberghe et al., 2014). In the RVG, Utescher et al. (2012) and Schäfer \& Utescher (2014) identify the level of the MMU in the Frimmersdorf lignite around the Langhian-Serravallian transition. More distal in the RVG, the MMU is expressed as a depositional hiatus surface at least spanning the earliest Tortonian (Munsterman et al., 2020). Hence also in Belgium, the observed hiatus between the Berchem and Diest Formations is most likely related to the larger scale MMU forming event in the North Sea Basin.

The thickness map of the Diest Formation presented in Figure 6 was produced using the basal surface map of Figure 5 and a new top surface of the Diest Formation. This is a reconstruction, for in the outcrop area, the formation is truncated and incised by the present terrain surface. A smooth flat surface connecting the top planes of the highest Hageland hills was constructed and then joined with the basal surface of the Kattendijk/Kasterlee Formations in the north as available in the G3D model.

The composed top surface is relatively smooth with a uniform slope dipping north. The dip increases from $0.2 \%$ in the southern part to $0.3 \%$ in the Noorderkempen. Therefore, the base Kattendijk/Kasterlee surface is a weakly expressed angular unconformity. The even morphology of the surface suggests it is a marine ravinement surface.

The Diest thickness map (Fig. 6), ignoring the thickness maxima situated in the elongated basal incisions, shows a uniform increase in thickness towards $\mathrm{N} 65^{\circ} \mathrm{E}$, i.e. orthogonal to the RVG. The wedge shaped thickness distribution probably reflects differential subsidence during the deposition of the Diest Formation, with stronger subsidence near the RVG border faults. Alternatively, or in addition to the previous, it may indicate stronger uplift after deposition of the more proximal SW part of the basin, followed by a more substantial truncation there. The overlying marine deposits all have an erosional base, often with a gravel. A truncation can also be inferred from regional profiles (e.g. profiles MG/0/280 and PGL/74/105, Laga, 1976).

The deviating thickness areas (filled channels or troughs) are clearly perpendicular to the RVG margin faults. The most important erosion troughs are situated near the SE margin of the "Diest Basin". In areas where the basal surface of the Diest Formation crops out, thick cross-beds are associated with the incised surface. Such exposures are in the flanks of long Hageland hills. Elsewhere, no clear relationship between incised basal depressions and the location of Hageland hills could be observed, apart from the fact that their long axes share the same "principal direction".

The faults bordering the RVG were active during the deposition of the Diest Formation. East of Dessel and Mol, the thickness of the formation abruptly increases from ca. $100 \mathrm{~m}$ west to ca. $150 \mathrm{~m}$ east of the faults there.

\section{Internal variation inside the Diest Formation}

Vandenberghe et al. (2014) suggested the Diest Formation might contain the sediments of two successive, separate Tortonian sedimentary sequences. The deposits associated with both sequences are in the present paper informally named the "Hageland Diest sand" and the "Kempen Diest sand", after their main area of occurrence.

The older Hageland Diest sand comprises the outcropping Diest Sand of Hageland and Zuiderkempen, which is mostly microfossil barren, along with the adjacent near-surface or subsurface units of the Diest Formation that contain dinoflagellate cysts of biochron DN8 (11 to 8.8 Ma, de Verteuil \& Norris, 1996). They are the Deurne Member, part of the Dessel Member (named hereafter the "DN8 Dessel sand" or the "lower Dessel Member"), and the lower part of the RVG Diest Sand and the easternmost outliers of the Diest Formation near Bree and Maaseik.

The younger Kempen Diest sand encompasses the upper part of the Dessel Member and the overlying Diest Sand found in the Noorderkempen and the RVG. These deposits yielded dinoflagellate biochrons DN9 and $10(8.8$ to $6 \mathrm{Ma})$.

The distinction between the two units relies mainly on differentiation in DN biozone (Louwye et al., 1999; Louwye \& Laga, 2008), K-Ar glauconite age (Vandenberghe et al., 2014), and heavy mineral associations (Hageland: larger portion of "southern" or "continental" provenance; Kempen: higher content of "marine" or "northern" source) (Verhaegen et al., 2019). The subdivision is however not (yet) firmly supported by

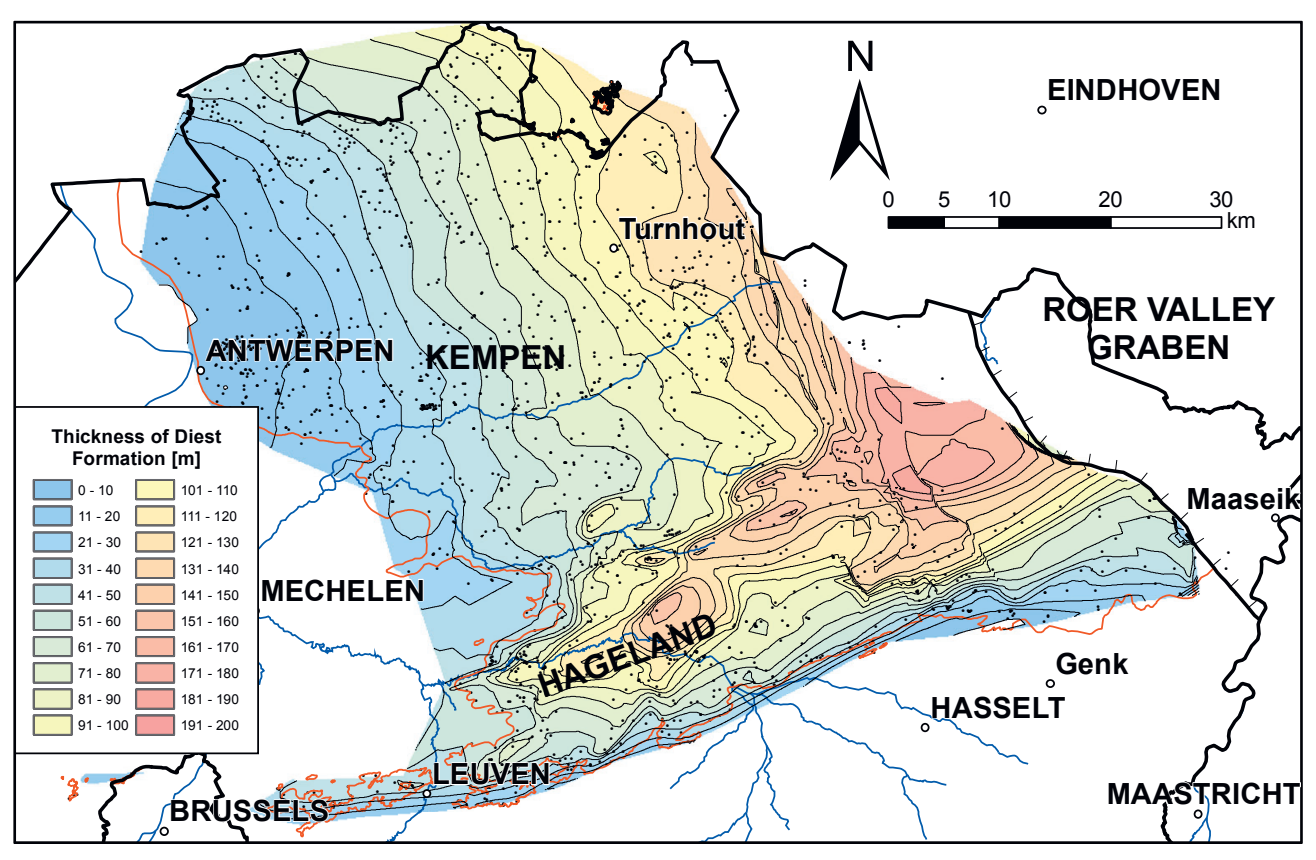

Figure 6. Thickness map of the Diest Formation (coloured) made from G3D data supplemented with elevations of the top surface of hills with an interior of Diest Sand. The basal surface version of Fig. 5 was used. 
differences in quartz grain shape and size, glauconite content, or type of biogenic traces. There is a difference in sedimentary structures and large-scale sedimentary architecture, but also this topic needs more extensive evidence. More specifically, a clear surface separating the two sedimentary cycles has not yet been recognized.

\section{Signature in geophysical logs}

Geophysical logs of natural gamma ray radiation (GR) and electrical resistivity (RES) show a diverse response throughout the Diest Formation. Annex C in Vernes et al. (2018) contains interpreted profiles with logs for the $\mathrm{H} 3 \mathrm{O}$ project area in the Belgian-Dutch border area, complemented to the north and the east in Munsterman et al. (2020). A comprehensive view to the south and towards the outcrop area is given here in Figure 7. As the Diest Formation is sandy throughout and often coarsening upwards, the Herselt log (GSB 060E0289 DOV B/1-1115a) represents the most representative response of a steadily upwards decreasing GR and increasing RES signal. The Zichem (GSB 076W0329 DOV BGD076w0329) and Scherpenheuvel (GSB 075E0340 DOV kb24d75e-B344) logs, situated near the Diest type locality, show a similar response in their top section, but they contain a thick basal part of constant values. In this interval, the sample descriptions mention sand and clayey sand with clay laminae. The about $170 \mathrm{~m}$ thick section at Lommel (GSB 032W0409 DOV kb17d32w-B379) shows a signature that matches well that of the about $100 \mathrm{~m}$ thick sections of Mol-Dessel (peilput S15/A 1 Mol GSB 031W0237 DOV B/10158, ON-Mol-2B GSB 031E0440 DOV ONMol-2B and ONDessel-5 GSB 031W0370 DOV ON-Dessel-5) and Weelde (GSB 008E0133 DOV kb8d8e-B26). Near Mol and Dessel, GR shows a steady, though sometimes discontinuous, upward increase over most of the interval, while RES exhibits more or less the mirror image. North of Mol and Dessel, in the $\mathrm{H} 3 \mathrm{O}$ project area, the base of the Diest Formation starts with a few metres of quickly upwards decreasing GR signal, followed by the same signature as at Mol. The latter would commonly be interpreted as a fining upwards sequence. The opposite is true: the Diest Sand has in most places a vertically constant or coarsening upwards profile. The high RES values indicate a high porosity, in this case for the basal section possibly related to well-sorted fine sand. The GR behaviour probably reflects variation in glauconite pellet content: the amounts increase upwards. At the current stage, there is no standard log pattern to represent the Diest Formation and also the lower and upper transitions have no characteristic or basin-wide recognizable signature. A closer look at more logs, in relation to biostratigraphic and lithologic data would be needed to allow sound geometric and genetic interpretations.

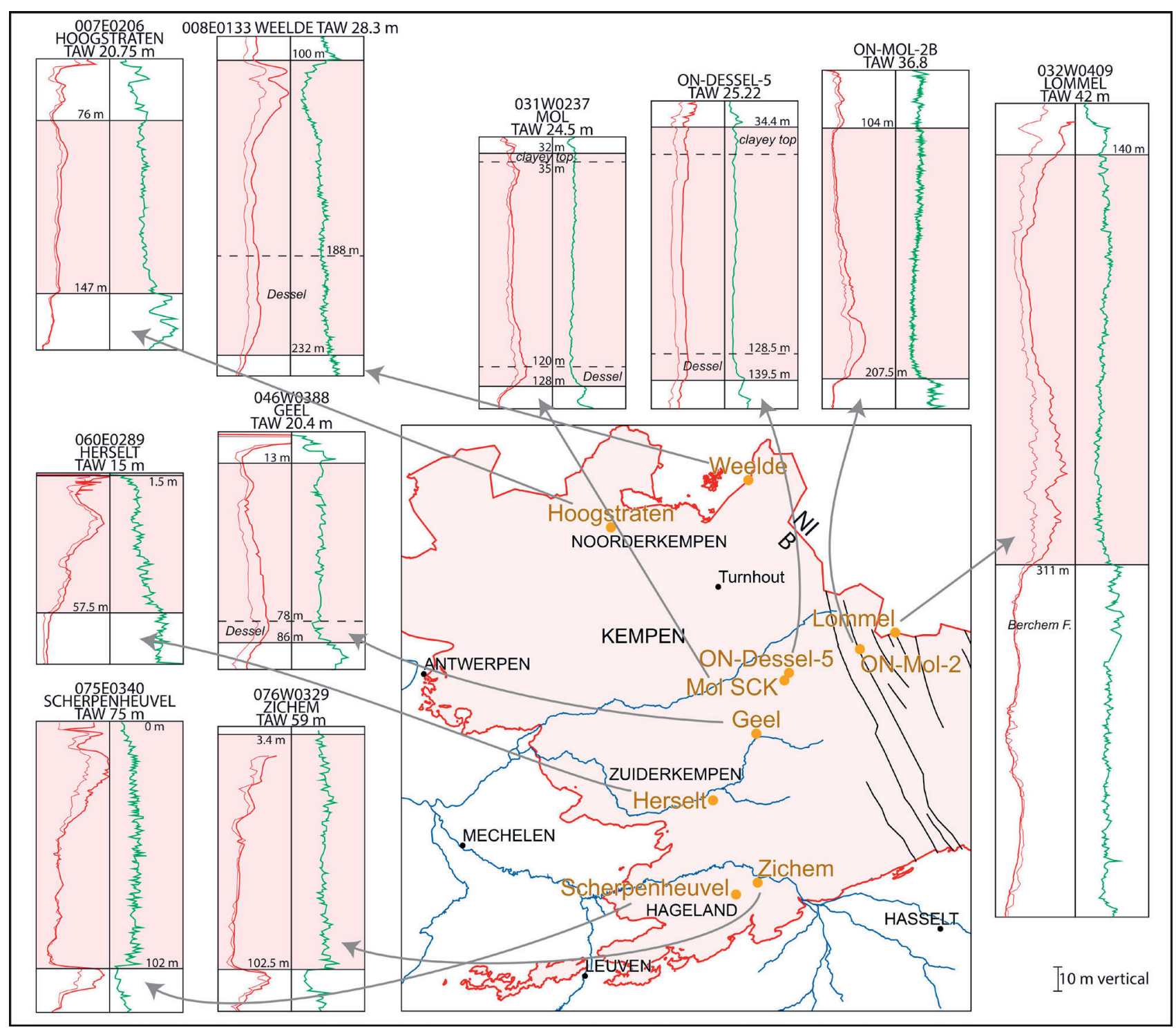

Figure 7. Selected GR and RES logs across the Diest Formation with interpretations taken from the description in the archives (this interpretation may vary according to author, e.g. "Dessel" in ON-Dessel-5 is thicker in Adriaens, 2015; possibly, in some interpretations "clayey top" is considered part of Diest Formation and in others of Kasterlee Formation). Red curves are long-normal (thick line) and short-normal (thin line) resistivity, green curves are natural gamma ray. 


\section{Regional expressions of the Diest Formation}

\subsection{Hageland}

The historic type area of the Diest Formation (Fig. 1a, b) offers numerous outcrops, often in abandoned sandpits, quarries, or temporary exposures when construction or road works take place. The stratotype is formed by exposures near the former town fortress at Diest (Laga et al., 2001). Informally but in accordance with the tradition, the deposits belonging to the Diest Formation in this area are called here "Hageland Diest sand". In many outcrops the grain size has a constant vertical trend. Due to the prolonged exposure to intensive oxidation, the glauconitic sand has locally been altered from greyish green to a sand with browncoloured bodies with irregular outlines (Fig. 8).

Dispersed in the sand(stone) matrix of the Hageland facies, some weathered flint granules occur, along with even more rare powdery white granules, consisting of poorly crystalline quartz and opal (Adriaens, 2015). Most likely, they represent (repeatedly) reworked silicified limestones of Mesozoic origin (Adriaens, 2015). Such very fine pebbles are not found inserted in the Dessel Member and the Kempen Diest sand.

Because any stratigraphically meaningful fossils are lacking in the Hageland Diest sand, its biostratigraphy and stratigraphic position within the Diest Formation remains uncertain. Vandenberghe et al. (2014) have suggested an early Tortonian age
(DN8 Zone) for the Hageland Diest sand based on the presence of the same DN8 Zone in the Dessel sand underlying the Hageland facies in the Veerle borehole (locations, see Fig. 1b) (GSB 060E215A DOV kb24d60e-B219), and in the Diest sand of the Wijshagen borehole (GSB 048W0180 DOV kb18d48w-B181). The latter has a more distal position with respect to the overall SW-NE transport direction indicated by the internal foresets of the Hageland Diest sand and has also comparable heavy minerals. However, the majority of Hageland Diest samples have never allowed direct biodating.

Houthuys (2014) described the following sedimentary facies found in outcrop:

- very thick cross beds (XT) (Fig. 8A, B, E): up to $6 \mathrm{~m}$ thick wedge or trough-shaped single cross-bed sets; they are tens of metres long and wide and thin towards their edges. Multiple pause planes occur (Fig. 8B); at such horizons often downwards colonizing by burrowing animals started; they are sometimes mud draped. Interpretation: deposits of very large 3D hydraulic dunes or channel-flank attached bars. descending cross beds (XD): individual cross-beds are bounded by parallel bedding planes descending both in the downcurrent and the transverse direction. Beds are mostly thinner than $1 \mathrm{~m}$. Interpretation: deposits of a suite of large hydraulic dunes descending a downcurrent and laterally sloping surface.
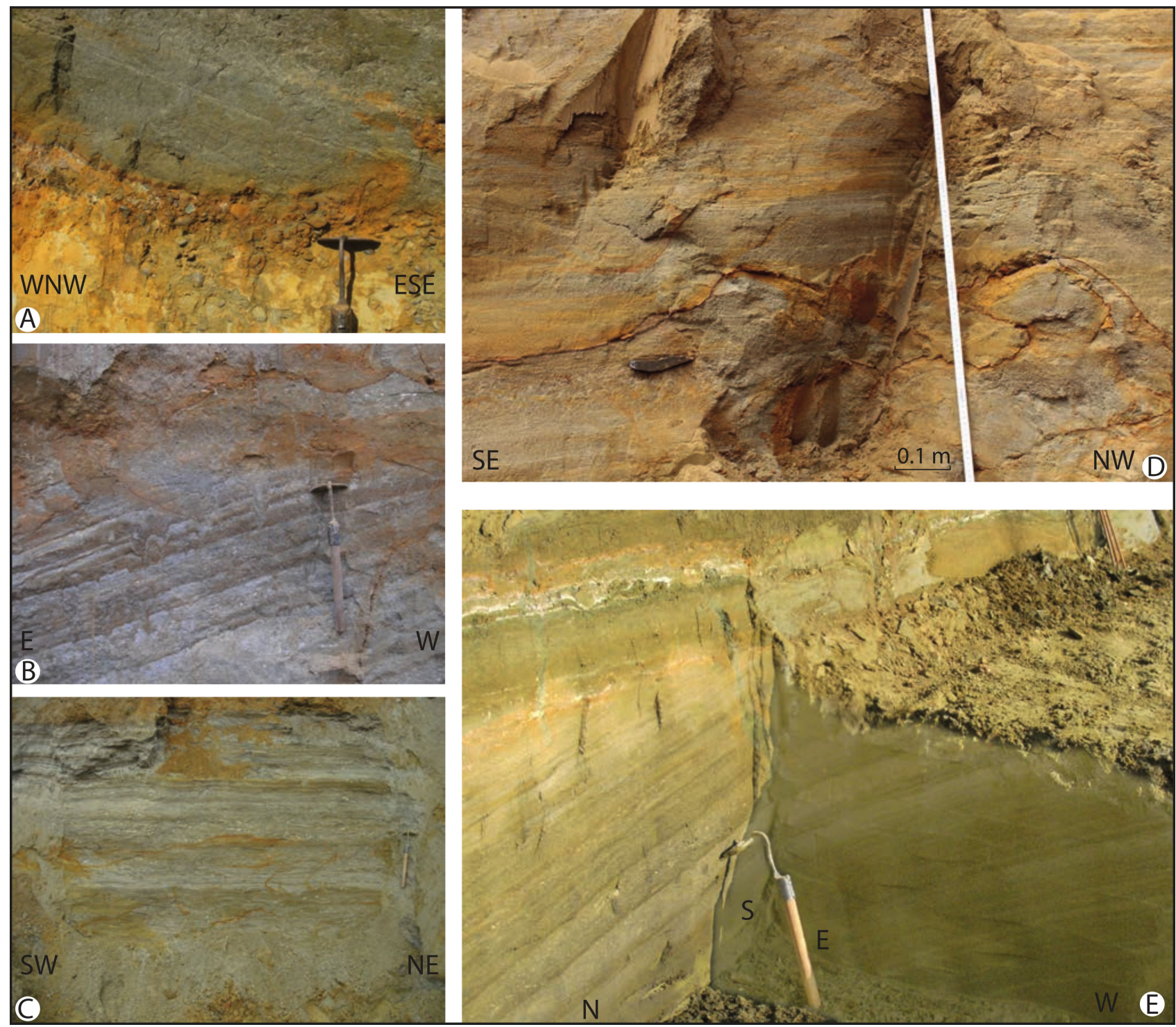

Figure 8. Outcrop photographs of Hageland Diest sand. A. Erosive contact of large-scale cross-bed on whitish fine marine sand of the Upper Eocene Sint-Huibrechts-Hern Formation in a temporary outcrop in 2014 near the entrance to Gasthuisberg Hospital at Leuven. The top of the white sand contains burrows filled with Diest sand. Note well-developed pebble layer at contact. B. Dip section of typical cross-bed in construction pit at Gasthuisberg Hospital in 2013. C. Strike section of the same cross-bed. D. Spaced planar lamination in Gasthuisberg outcrop in 2018. E. Scarcely bioturbated thick cross-bed and base of covering cross-bed containing clay drapes. Construction pit in Veltem $5 \mathrm{~km}$ WNW of Leuven, 2012. Scraper tool in photos is about $40 \mathrm{~cm}$ long. 
bioturbated descending beds $(\mathrm{Bx}): 0.1$ to $0.2 \mathrm{~m}$ thick, bioturbated beds with parallel bedding planes descending both in the downcurrent and the transverse direction. Interpretation: deposits of small hydraulic dunes, descending the downcurrent face of a channel flank-attached bar and thus causing it to accrete downcurrent and laterally; slower deposition than previous facies.

bioturbated fine $(\mathrm{Bf})$ or medium $(\mathrm{Bm})$ sand. Primary structures completely homogenized though in some parts traces of thin cross beds can be recognized. Interpretation: mixed deposit of suspended very fine sand and mud, and probably only occasionally active, low dunes.

massive to vaguely laminated, unbioturbated sand (M), to which can be added from a recent outcrop (DOV VLA174.1-001-TO1) spaced planar lamination (Mp) (Fig. 8D): both facies are deposits from breaching turbidites (van den Berg et al., 2017). They were up to now not often recognized and only in thicknesses of a few decimetres.

It is remarked that the inventory of facies is probably not complete as good outcrops are rare.

Nearly all foreset laminae of cross beds dip to the sector NENNE, with a small direction spread (Houthuys, 2014), i.e. they indicate currents flowing along the principal direction of the Hageland Diest sand, toward the RVG. Beds with opposite dip directions occur rarely. The depositional environment was tidal, with relatively well constrained flow directions.

The facies are strongly interwoven, in the way described by Houthuys (2014) and Houthuys \& Matthijs (2018); see also Figure 9. The beds show a dominance of a downstream progradational fill (Fig. 9a). Due to outcrop limitations, we are less well informed about the larger-scale transversal structure. Most outcrops that allow flow-transverse observations indicate there is a lateral fill component, with a dominance of largescale bedding planes that dip to south or SE (Fig. 9b). Figure 10 sketches the reconstructed depositional environment as a fill of palaeochannels or troughs. The original bedforms migrated downstream in the principal direction, but also laterally,

SW
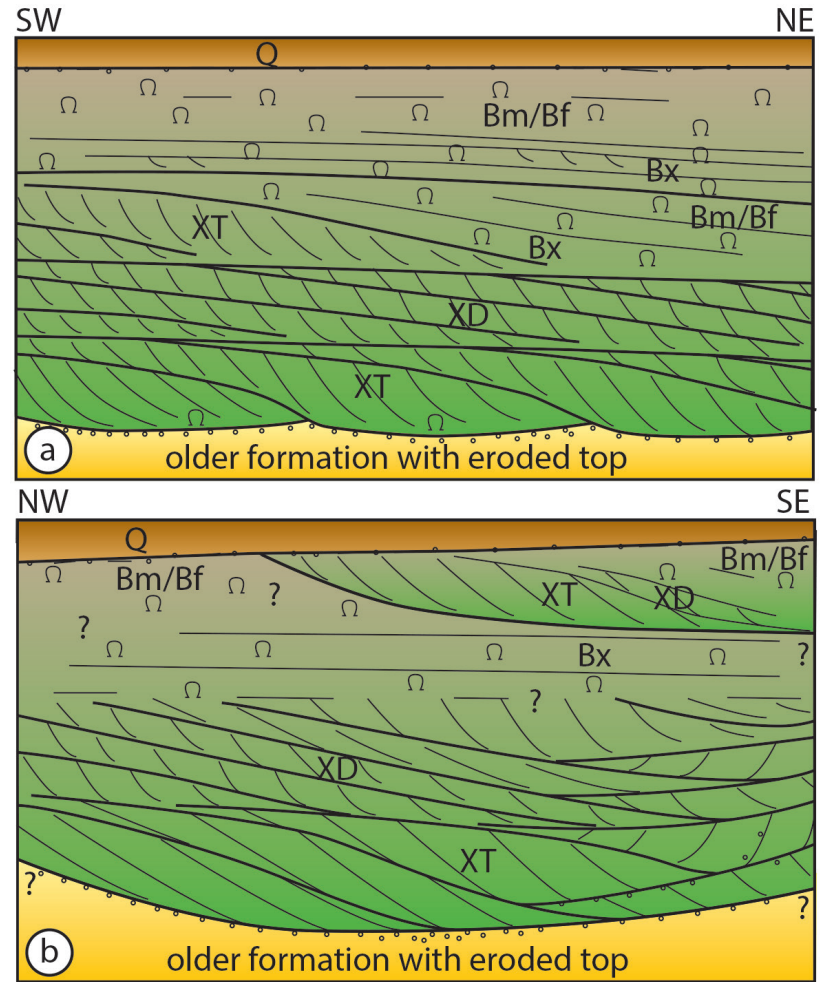

Figure 9. Idealized longitudinal (a) and transverse (b) sections through a Hageland hill. Dimensions are in the order of 50-100 $\mathrm{m}$ for the horizontal and 10-20 $\mathrm{m}$ for the vertical. Omega sign denotes bioturbation. Letters indicate sedimentary facies (see text). Note that thick cross-beds may also be found higher in the profile. Q denotes Quaternary reworked sediments and sandy löss cover. towards the south and SE (Fig. 10a). The presence of breaching turbidites (facies $\mathrm{M}$ and $\mathrm{Mp}$ ) and the geometry of the turbidite beds confirms the flow was channelized: breaching is a type of failure of a (steep) channel side (van den Berg et al., 2017) (see Fig. 10b). On a larger scale, some stacking of channels can be inferred. The channels all had more or less the same long axis: the principal direction.

The top of the Hageland Diest sand is a truncation surface. In Hageland, no younger marine sediments are found on top. The highest hills and the plateau remnants have a smooth flat top surface lined with weathered, rounded flint pebbles, among which some larger than $10 \mathrm{~cm}$. It has been interpreted as the Diest Formation's "regressive gravel" (Vandenberghe \& Gullentops, 2001). Alternatively, Houthuys \& Matthijs (2018) supposed the truncation surface is formed by marine ravinement, probably related to the Kasterlee transgression, rather than by continental peneplanation.

\subsection{City of Antwerpen area: the Deurne Member}

The Deurne Sand (Glibert \& de Heinzelin, 1955a,b) is a member of the Diest Formation (De Meuter \& Laga, 1976) (Fig. 3). Its occurrence is restricted to a limited area around the city of Antwerpen. It is a glauconiferous, slightly clayey, calcareous, medium- to fine-grained glauconitic sand unit situated in the lower part of the Diest Formation (Figs 2, 3). It is locally rich in bryozoans, brachiopods and Ditrupa (calcareous worm tubes). De Meuter \& Laga (1976) only mentioned 'Deurne' as type locality and 'temporary exposures of shallow excavations at Deurne' as type section. Bosselaers et al. (2004) proposed as type section
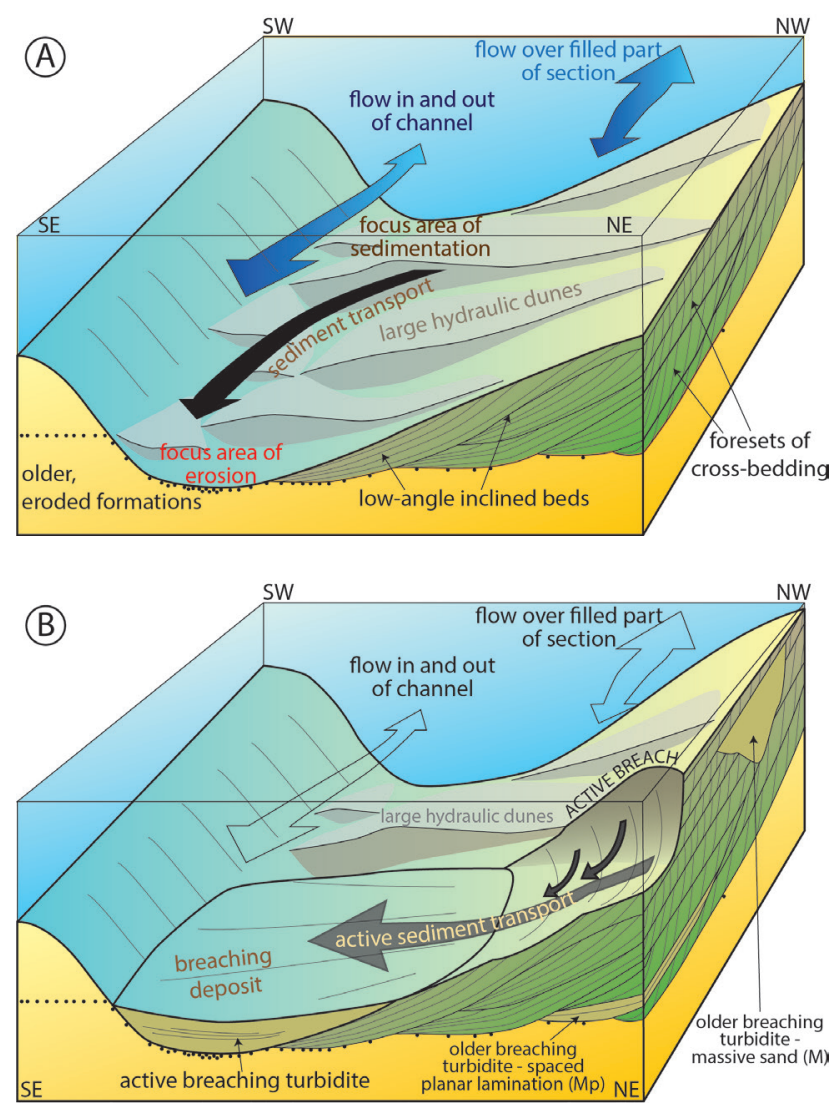

Figure 10. Reconstruction of the sedimentary processes that governed deposition of the Hageland Diest sand. a. Channel or trough flow associated with cross-bedding. Grey-shaded bedforms are large subaquatic dunes. They were most probably covered by smaller dunes (not indicated in sketch). b. Illustration of a breaching event during fill of a channel. The breach at the NW side of the channel can keep a steep, almost vertical flank due to the slightly compacted nature of the sediments into which it cuts (see van den Berg et al., 2017). The active sediment transport related to the breaching event is a turbidity current. Breaching will ultimately stop when the turbidite deposit becomes so thick that it fills the breach. The sketch also illustrates the depositional facies associated with breaching. 
an outcrop named "VII BR Borgerhout Rivierenhof" near the Antwerpen motorway ringroad, described by De Meuter et al. (1966, fig. 2, section A), De Meuter \& Laga (1970, fig. 1) and De Meuter et al. (1976, fig. 17). Here, the Deurne Sand is found inserted between the top of the Antwerpen Sand (Berchem Formation) and the base of the Kattendijk Formation, and is less than $1 \mathrm{~m}$ thick. A thicker sedimentary interval of about $5.60 \mathrm{~m}$ attributed to the Deurne Member was meticulously described by Bosselaers et al. (2004) during construction works at the Maria Middelares Hospital in Deurne, about $1.5 \mathrm{~km} \mathrm{SE}$ of the proposed type section. The section contained bioturbated sand with a rich marine macrofauna.

Biostratigraphic dating by dinoflagellates, foraminifera and bolboforma place the Deurne Member within the mid Tortonian (King, 2016). Dinoflagellate cysts situate the Deurne Member within the DN8 zone (11-8.8 Ma) of de Verteuil \& Norris (1996) (Louwye, 2002). A review of various publications allowed King (2016) to refine the positioning to his Subzone NS40b (9.5-8.8 Ma).

A large temporary outcrop (construction of bypass road R11 tunnel underneath the Antwerp International Airport runway, near Borsbeek, see Fig. 1b) (Goolaerts et al., 2020, this volume) revealed two superimposed units in the $5.50 \mathrm{~m}$ thick Diest Formation of the area: a lower unit of green glauconiferous sands with a coarse but disperse base gravel, and an upper unit with more blueish coloured glauconiferous sands with a fine gravel at the base of large channel trough forms. Both units have a very different grain size, glauconite content and trace fossil association (Fig. 11B versus C). Also, while large-scale primary sedimentary structures are seemingly absent from the lower unit, several large trough cross-beds and inclined beds make up the upper unit (Fig. 11A, D, E). The upper unit has a variable thickness with an erosive, incised base that locally cuts through the lower unit down to the underlying Berchem Formation. The long axis of the cross-bed troughs trends west-east and the large-scale foresets inside them dip to the east. The clay mineralogy of the upper unit is relatively smectite-rich and the pelletal glauconite content ranges between $39 \%$ and $46 \%$ (Adriaens, 2015). Both units are fossiliferous. The high amount of dissociated and associated skeletal remains of marine mammals in the lower half of the lower unit is remarkable. Some of the palaeontological specimens from this outcrop have already been the subject of published studies (e.g. phocid remains in Dewaele et al., 2017; Elasmobranchi in Hoedemakers \& Dufraing, 2015), others will follow. Possibly, the superposition of the two units is regional (Goolaerts et al., 2020, this volume).

As to sedimentary facies, the lower unit can be seen as a local representation of the Hageland Diest sand's facies Bf or Bm, and the upper unit of facies XT. The foreset directions are similar. The entanglement of facies observed in Hageland includes the contacts observed at Antwerp International Airport.

\subsection{Antwerpse Kempen: Dessel Member and Kempen Diest sand}

The part of the Diest Formation just east of the Deurne Member and north of the area with the complex, deep incisions at the base (Figs 1b, 4, 5) occupies most of the Kempen in the province of Antwerpen. Here, the Diest Formation is present in an increasing thickness, exceeding $100 \mathrm{~m}$ in the east, mostly as a highly glauconiferous fine sand grading upwards into a medium-coarse sand. The fine-grained lower part is the Dessel Member, the coarser main unit above it is named here "Kempen Diest sand". The vertical transition between the Dessel and Kempen Diest units is placed at a change in grain size, using the modal grainsize value of $200 \mu \mathrm{m}$ to separate them. This change is not abrupt, it takes place as a gradual transition.
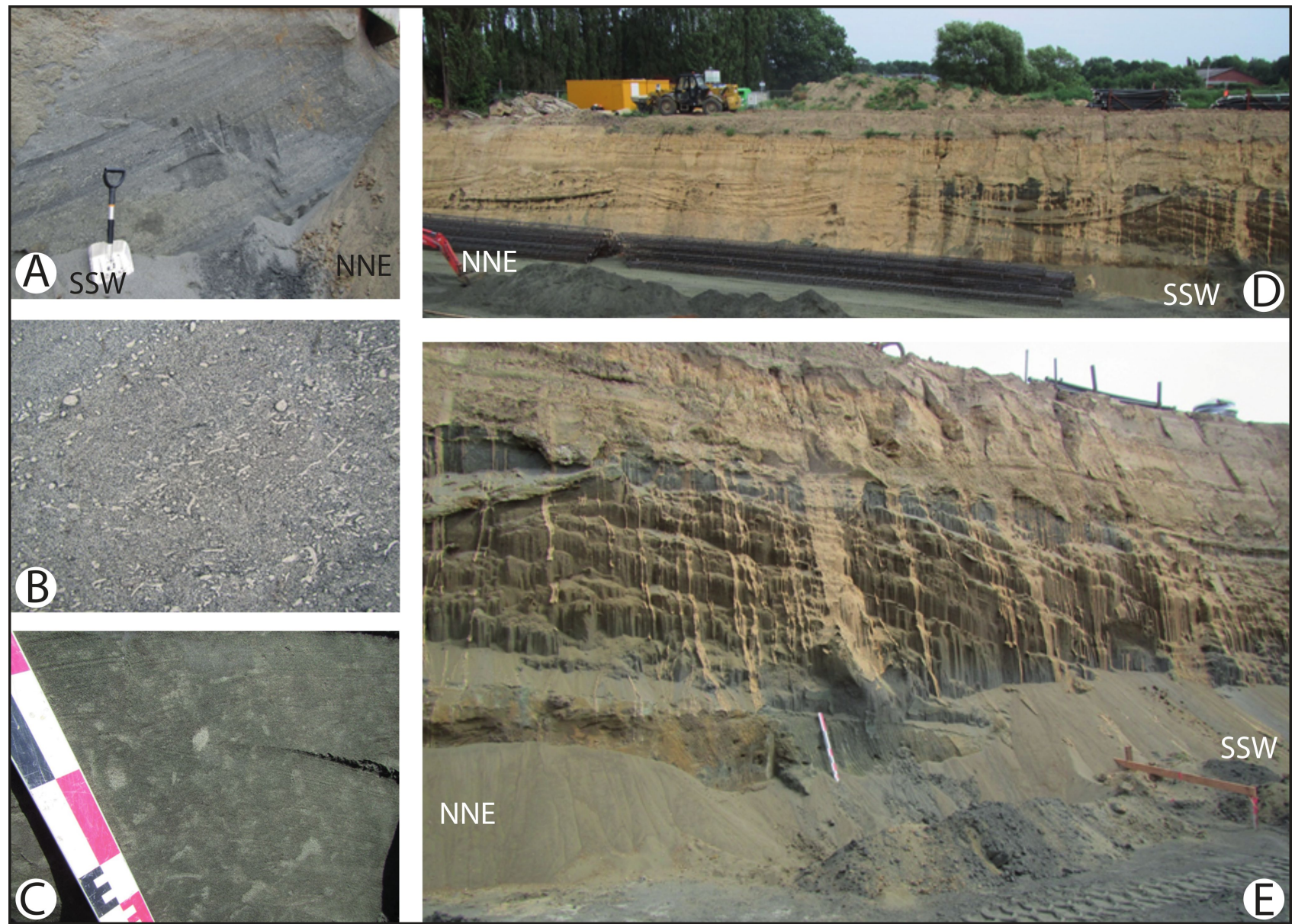

Figure 11. The Deurne Member of the Diest Formation at the Antwerp International Airport outcrop consists of two units, of which the upper one shows large-scale trough cross-bedding, much like the cross-bedding of the Hageland Diest sand. Both the lower (C) and upper (A, B) unit are intensely bioturbated, but have a remarkably different ichnofabric. (D) Large scale sedimentary structures in the upper unit in the ESE wall of the construction pit of the northern access lane to the tunnel. (E) Large scale sedimentary structures in the upper unit. Same wall as previous photo, but taken some more to the right, still partly overlapping with previous photo. Base of the upper unit sits near the top of the $1 \mathrm{~m}$ scale bar. Photos taken on 2 August 2014 . 


\subsubsection{Dessel Member}

The Dessel Member (Laga \& De Meuter, 1972) is a glauconiferous sand essentially defined by its fine grain size. It is present in the subsurface of the Antwerpse Kempen as the basal unit of the Diest Formation. A gravel occurs at the base; but it is only a thin layer of coarse grains and it is not found systematically in all boreholes. According to the original definition, the lower part of the Dessel Member is rich in calcareous microfossils (Laga \& De Meuter, 1972). In practice however, the member was primarily identifed based on the grain-size criterion. Throughout the basin, fine-grained sand without carbonates is present in the lower part of the Diest Formation, either above the calciferous part (in this case, some authors distinguish a "lower part" and an "upper part" of the Dessel Member, see Fig. 3) or replacing it.

Using only the grain-size criterion implies the complete Dessel Member reaches a thickness of almost $30 \mathrm{~m}$ both in Rijkevorsel (GSB 016E0153 DOV kb8d16e-B37) as well as in the Dessel area. Adopting the stricter criterion of holding carbonates would result in only $11 \mathrm{~m}$ of Dessel Member in the ON-Dessel-5 (GSB 031W0370 DOV ON-Dessel-5) well (Labat et al., 2011).

Apart from grain size, also clay mineralogy suggests the lower and upper parts of the Dessel Member should be grouped in one unit (Adriaens, 2015). They are both rich in smectite in contrast with the interstratified glauconite/smectite clay mineralogy of the Kempen Diest sand above it. Pelletal glauconite content is on average $26 \%$ and the mineralogy of the pelletal glauconite is very similar to the Berchem glauconite pellets, with $>11 \%$ expandable layers. The Dessel Member can also be distinguished from the Kempen Diest sand by its higher content of northern components in heavy mineral assemblages (Verhaegen et al., 2019; Verhaegen, 2020, this volume). The Dessel Member is strongly homogenized by bioturbation and often shows $\mathrm{mm}$ - to about $1 \mathrm{~cm}$ wide burrow traces (Fig. 12B).

Dinoflagellate cyst biozones of reference boreholes, such as the Pidpa Oostmalle (GSB 029E0249 DOV kb16d29e-B276) and the Pidpa Retie (GSB 031W0243 DOV kb17d31w-B228) boreholes (Louwye et al., 1999) show that both the DN8 (118.8 Ma, early and mid Tortonian) and DN9 Zones (8.8-7.5 Ma, late Tortonian) are recognised in the Dessel Member. The DN8 Zone is relatively thin, and approximately coincides with the thin lower calcareous Dessel facies, while the largely non-calcareous upper Dessel facies approximately correlates with the DN9 biozone (Adriaens, 2015). There seems to be a relation between the DN9 Zone occurrence of the Dessel Member and absence of carbonates, not only observed in the two boreholes mentioned above, but also confirmed in the lithological descriptions of samples in the borehole reports of the Pidpa Poederlee (GSB 030W0300 DOV kb16d30w-B315) and Mol (GSB 031W0221 DOV kb17d31w-B212) boreholes (Louwye et al., 1999). It is not known whether this change would be related to decalcification or to a change in depositional conditions.

A K/Ar age of 11.4 and $11.5 \pm 0.4 \mathrm{Ma}$ was found for a glauconite sample taken at 139 to $139.5 \mathrm{~m}$ depth in the ONDessel-5 borehole (Vandenberghe et al., 2014). This is near the base of the Dessel Member and may represent a true age of deposition provided the sample contained autochthonous glauconite. Samples from various boreholes to the west and NW of Dessel all returned older ages, from Langhian to even Burdigalian times and suggest that these glauconite pellets are reworked (Vandenberghe et al., 2014).

The precise geographical extent of the Dessel Member remains to be mapped. It appears to have a sheet-like occurrence over the Antwerpse Kempen, although in some boreholes only coarser grained Diest Sand was observed (Louwye et al., 1999; Adriaens, 2015). Also the lateral extent and possible lateral transitions remain to be elucidated.

\subsubsection{Kempen Diest sand}

In the Antwerpse Kempen, the Dessel Member is overlain by a tens of metres thick unit of the Diest Formation called here "Kempen Diest sand". It is a medium to coarse, poorly-sorted and loosely-packed sand ("heteromorphic" in descriptions by Gulinck and Laga in the Archives of the Geological Survey of Belgium), with a very low clay content and a high content of pelletal glauconite. This unit corresponds to lithofacies D1 of Adriaens

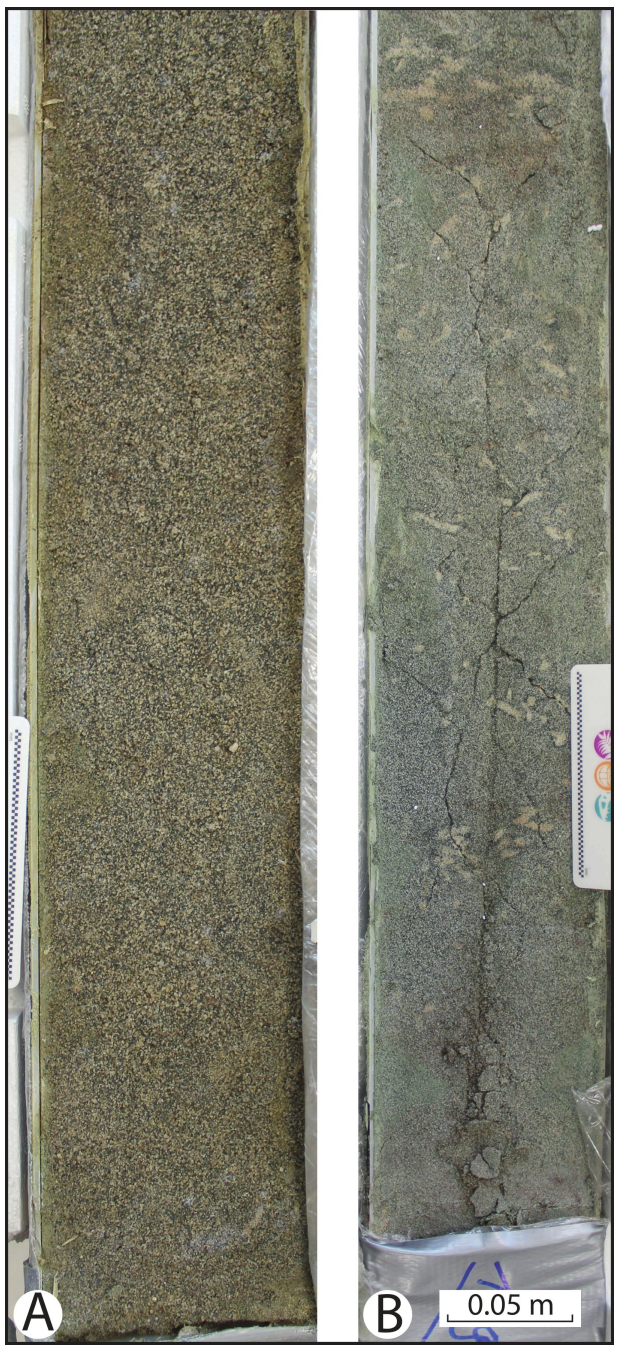

Figure 12. Diest Formation bioturbation structures in cores. The cores are approximately $10 \mathrm{~cm}$ wide. A. Beerse (GSB 017W0354 DOV 2022 167), basal part of core at depth $89-90 \mathrm{~m}$. Poorly sorted and intensely bioturbated coarse sand with granules of the Kempen Diest sand; individual burrows are difficult to recognize. B. Beerse, basal part of core 128-129 m. Fine sand of the Dessel Member, with different densities of bioturbation structures.

(2015). Locally a thinner unit of lithofacies D4 (Adriaens, 2015) may occur on top of it.

Characteristic for lithofacies D1 is the coarse grain size with significant amounts of particles coarser than $500 \mu \mathrm{m}$. Coarse elements are usually angular quartz grains that may reach about 2 $\mathrm{mm}$ in size. The mode of the distribution typically lies in the 300 $400 \mu \mathrm{m}$ interval but occasionally also in the $250-300 \mu \mathrm{m}$ interval. The low amount of dispersed clay mainly consists of clay-sized glauconite with hardly any smectite. Glauconite pellet contents are on average $40 \%$ but range from 20 to $60 \%$ (Adriaens, 2015). Glauconite pellets are most abundant in the very coarse sized samples. The mineralogy of pelletal glauconite consists of low amounts of expandable layers $(<8 \%)$, which is very characteristic for this facies.

Clear primary sedimentary structures such as cross-bedding are very rare or absent; homogenization due to bioturbation appears to be the dominant structure (Fig. 12A). The heavy mineral content of the Antwerpse Kempen Diest sand is highly variable indicating significant mixing between southern and northern sources (Verhaegen et al., 2019).

The Kempen Diest sand contains no calcareous microfossils but dinoflagellate cysts are found and biozones DN9 (8.8-7.5 $\mathrm{Ma})$ and DN10 (7.5-6.0 Ma, latest Tortonian to early Messinian) were reported by Louwye et al. (1999), Louwye et al. (2007), Louwye \& Laga (2008) and Louwye \& De Schepper (2010). The bulk of the Kempen Diest sand is DN9 (late Tortonian) but 
towards the northwest, sediments containing DN10 biozone (Tortonian-Messinian) overlie and replace them (Fig. 13).

$\mathrm{K} / \mathrm{Ar}$ dates determined on glauconite samples from various boreholes in the Antwerpse Kempen all returned ages from Langhian and even Burdigalian times, which suggests reworking (Vandenberghe et al., 2014).

In the Mol-Dessel area, on top of the Kempen Diest sand, a 1 to $5 \mathrm{~m}$ thick unit of coarse glauconiferous sand alternating with $\mathrm{cm}$-scale brown to violet pure clay layers is found. This unit, informally named "clayey top of Diest Formation" (Wouters \& Schiltz, 2012), is commonly considered part of the Diest Formation (Gulinck et al., 1963). However, as in the same area similar deposits containing clay and sand alternations of the lower part of the Kasterlee Formation are found, it is difficult to place a well-defined boundary between a clayey Diest Formation top and a clayey Kasterlee Formation base (Vandenberghe et al., 2020, this volume). The clayey top of the Diest Formation is also lithologically a facies ("D4") that can be differentiated from the bulk of the Kempen Diest sediments (Adriaens \& Vandenberghe, 2020, this volume). It typically contains poorly sorted sand with distribution modes ranging between 170-250 $\mu \mathrm{m}$ and an elevated clay content. It is very rich in expandable minerals and is characterized by both dioctahedral smectite and trioctahedral Fe-rich vermiculite. Although siderite and phosphate minerals (vivianite, fluorapatite) occur in all of the Kempen Diest sand, the highest concentrations are found within the Diest D4 unit (Adriaens, 2015). As the Diest D4 facies is mainly defined based on the presence of Fe-vermiculite and less based on grain-size characteristics, also coarser-sized D4 sediments occur, such as in the Rees borehole (GSB 017E0399 DOV kb8d17e-B495). Pelletal glauconite amounts are relatively high $(32.9 \%)$ but on average slightly lower than in the bulk of the Kempen Diest sand (37.9\%). The mineralogical composition of lithofacies D4 is interpreted as a depositional unit that received input from weathered, glauconite-rich soils (Adriaens \& Vandenberghe, 2020, this volume). Lithofacies D4 samples yielded dinoflagellate cyst biozone DN10 (Louwye et al., 1999; Adriaens, 2015), but in the top $5 \mathrm{~m}$ of the Diest Formation in the ON-Dessel-2 (GSB 031W0338 DOV kb17d31w-B299) borehole, DN9 was reported (Louwye et al., 2007). This matter needs further sorting out.

\subsection{Limburgse Kempen and Roer Valley Graben}

The Diest Formation in the central part of the province of Limburg (Fig. 1b) has some characteristics in common with Diest Sand of the Hageland area, though toward the NE it becomes less thick, finer grained and the cross bedded facies no longer occur. Further on, beyond the RVG border faults, the formation is thicker again. Near and inside the RVG, bioturbated, relatively fine, glauconiferous facies dominate.

The Wijshagen borehole is located about $3.5 \mathrm{~km}$ south of the RVG border fault system (Fig. 1b) and just SE of the area where deep incisions in the base of the Diest Formation may be present (Figs 4, 5; possible incisions are poorly documented in this area). Above a base containing some coarse quartz sand, but no base gravel, at $87.5 \mathrm{~m}$ depth (absolute elevation $-23 \mathrm{~m}$ ), a lower ca. 9.5 $\mathrm{m}$ thick unit of fine-grained, bioturbated glauconiferous sand is followed by an upper ca. $25 \mathrm{~m}$ thick unit of fine to medium grained, blackish green, bioturbated sand; no indication of crossbedding is present (Houthuys \& Matthijs, 2020, this volume). The interval identified as Diest Formation displays a weak coarsening upwards trend. It was assigned to biozone DN8 (Louwye \& Laga, 2008).

A few kilometres to the east, a small, 3 to 4 m thick outlier of glauconiferous and burrowed sand with silicified shells at the base, that was well exposed in a number of sandpits SW of Opitter (Fig. 1b), used to be a part of the Diest Formation (Mourlon, 1898; Gullentops, 1963; Gullentops \& Huyghebaert, 1999). It was later singled out as the Gruitrode Molen Member of the Diest Formation (Sels et al., 2001; Sintubin et al., 2001). The 2002 Opitter seismometer well (GSB 048E0294 DOV BGD048e0294) showed that the Diest Formation is indeed present at that location, but as a $38 \mathrm{~m}$ thick fine, glauconiferous sand, only found in the subsurface at deeper levels and not in outcrop. The glauconiferous sand observed in outcrop is consequently younger and no part of the Diest Formation. It is described and palaeo-environmentally interpreted by Houthuys \& Matthijs (2020, this volume).

Five $\mathrm{km}$ to the southeast, a "Neeroeteren facies" was described by Gulinck (Geological Survey of Belgium archive, 1964) in borehole GSB 064W0234 (DOV kb26d64w-B242) as a local representation of the Diest Sand. But this too probably correlates to a younger formation.

The Maaseik Jagersborg borehole (GSB 049W0220 DOV $\mathrm{kb} 18 \mathrm{~d} 49 \mathrm{w}-\mathrm{B} 220)$ is located inside the RVG, at about $6 \mathrm{~km} \mathrm{NE}$ of its bordering Feldbiss-Neeroeteren Fault system. Based on benthic foraminifera and ostracods, an equivalent of the Deurne-Dessel Member was identified at the depth interval 198$234 \mathrm{~m}$ (Vandenberghe et al., 2005). This sand is fine-grained, moderately clayey, glauconiferous and contains shell debris and carbonates. There is a subtle coarsening upwards trend and the glauconite content also increases upwards. The sedimentary characteristics, lithology and thickness are similar to those found at Wijshagen. Dinoflagellate cyst analysis assigned the interval above $220 \mathrm{~m}$ to biozone DN9, and the interval below 220 $\mathrm{m}$ to DN8. The DN8 interval extends further down below $234 \mathrm{~m}$, to $272 \mathrm{~m}$, beneath which DN6 and DN7 were found. The lower part of the DN8 interval has no known correlate in the Kempen.

New analyses found that a ca. $32 \mathrm{~m}$ thick sand unit above it, described as "bed X" (198-192 m) and the lower part of the Waubach Member (192-166 $\mathrm{m}$ ) by Vandenberghe et al. (2005), is a lateral equivalent to the DN9 Kempen Diest sand (Verhaegen, 2020, this volume; Louwye \& Vandenberghe, 2020, this volume). The lower part of the Waubach Member is now also regarded as the local continuation of the upper Miocene Inden Formation (Fig. 3). This unit is medium to very coarse grained and locally gravelly in the Maaseik borehole and contains transported lignite grains (Vandenberghe et al., 2005). It is interpreted as a braided river deposit.

The Limburgse Kempen Diest sand heavy mineral content is very similar to the Hageland Diest heavy mineral content and is also strongly mixed. The andalusite/kyanite ratio is intermediate between the Hageland and Antwerpse Kempen Diest sand (Verhaegen et al., 2019).

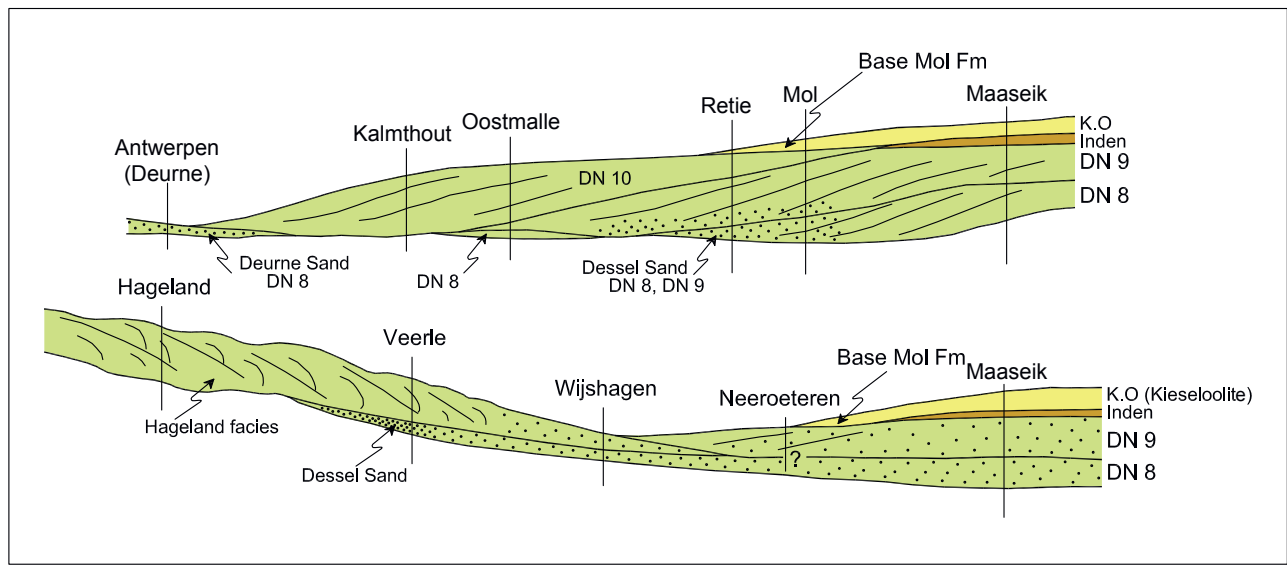

Figure 13. Internal geometry and progradation directions within the Diest Sand (light green) summarized by Vandenberghe et al. (2014). The lower profile is from SW (Hageland) to NE (RVG, Maaseik), the upper profile is more to the north from west (Antwerpen) to east (RVG). Dotted areas informally represent fine sand. 
In summary, east and RVG-ward of the deep incisions in the base, the Diest Formation is represented by fine, bioturbated facies in smaller thicknesses than inside the incisions. No structures related to strong currents are found in the available cores. Inside the RVG, a DN8 unit lacking a correlate elsewhere in the Diest basin is found, followed by a fine-grained, glauconiferous DN8 unit (lateral correlate to the Deurne Member), a slightly coarser grained, glauconiferous DN9 unit (lateral correlate to the Dessel Member) and a fluvial DN9 part (Inden Formation, lateral correlate to the Kempen Diest sand). Good descriptions of the thick development of the Diest Formation inside the RVG more to the north, are still lacking.

\subsection{Flemish Hills}

West of Brussels, the summits of the Flemish Hills from Flobecq in the east to Cassel (N. France) in the west (Fig. 1a) contain an up to $25 \mathrm{~m}$ thick package of slightly glauconiferous, near the top locally more glauconiferous sand. They were traditionally considered to be western outliers of the Diest Formation (Dewalque, 1868; Delvaux, 1884; Tavernier \& de Heinzelin, 1962), and were thought to represent its ancient shoreline (Gullentops, 1988).

This so-called "Flemish Hills sand" (Houthuys, 2014) is heavily weathered and locally iron cemented, a characteristic it shares with the Diest Sand in the Hageland hills. Also the pelletal glauconite mineralogy and the occurrence of opaline pebbles favour some mineralogical similarities with the Hageland Diest sand. However, with no macro- or microfossils ever having been found in the Flemish Hills sand, the only objective age dating relies on its stratigraphic position in the Paleogene-Neogene succession (Houthuys, 2014). Its lithology and sedimentary structures were described in detail by Houthuys (2014). Its finegrained nature, the dispersed occurrence of large pebbles, the entirely different depositional environment (Houthuys, 2014) and kaolinite-rich clay mineralogy (Adriaens, 2015) allow to clearly distinguish the Flemish Hills sand from any other Diest Formation deposit.

Houthuys (2014) argued, based on the relative stratigraphy, the high content of dispersed pebbles, and also on considerations regarding the origin of the present-day overland drainage network, that the Flemish Hills sand must be considerably older, possibly upper Eocene. He proposed the new name of Flemish Hills formation for these sands. Various other proposals have been made. Gulinck (1960) suggested they were part of the (now upper Pliocene) Poederlee Formation. Based on the shape similarity of the pebbles at the base, a possible correlation to the Miocene Bolderberg Formation was suggested by Adriaens (2015). Leriche (1929) proposed they were a lateral equivalent of the lower Oligocene Berg Sand. The study of heavy minerals of these sands could neither prove nor disprove their omission or inclusion in the Diest Formation (Verhaegen et al., 2019; Verhaegen, 2020, this volume). Only additional data will allow to unravel their age and correlation.

In this discussion, the close study of a very local sand unit found on a plateau south of Kraainem, east of Brussels (Fig. 1b), may be important. It is a $14 \mathrm{~m}$ thick, coarse-grained, locally pebbly, sand deposit, clayey at its base and with limonite-cemented stone plates near the top. The interval was described by Mourlon (1904) who assigned it to the "tongrien 2 continental" (now uppermost Eocene or lowermost Oligocene). Leriche (1929) argued they were a lateral equivalent of the lower Oligocene Berg Sand. The lithological characteristics of this unit are strikingly similar to the Flemish Hills sand while it occurs in close proximity to known occurrences of Diest Sands.

\section{Spatial relationships between the different units of the Diest Formation}

\subsection{Evidence from seismic surveys}

The 1990s seismic survey of the canals in the Flemish Region provided a good coverage of the subsurface in the Kempen area (De Batist \& Versteeg, 1998). The most outstanding features for the Diest Formation in this area are (location names are shown in Fig. 14b): it has an irregular (erosive) basal surface in the area around Kwaadmechelen and also inside the RVG between Lommel and Bocholt;

at least inside the part of the RVG near Bocholt, the formation contains two stacked units: a lower one ("Mi2"), approximately $50-75 \mathrm{~m}$ thick, with chaotic reflections, separated by an unconformity from an upper one ("Mi3"), up to $150 \mathrm{~m}$ thick, with impressive, NW-prograding inclined beds and aggrading topsets.

The detailed and interpreted results of the surveys behind De Batist \& Versteeg's (1998) publication are kept at the Flemish Authorities' Vlaams Planbureau voor Omgeving, Team Ondergrond en Diepe Ondergrond. These show more profiles than the published ones and present also some internal reflectors in the Diest Formation in the area outside and fringing the SW border of the RVG. Most of the unpublished features interpreted at the time have been reconsidered and confirmed as trustworthy (Marc De Batist, pers. comm., 2019).

In addition to the features published in De Batist \& Versteeg (1998), a remarkable structure is an isolated, $80 \mathrm{~m}$ deep (with respect to the surrounding, more or less level basal surface) and $2 \mathrm{~km}$ wide (along the Albert Canal) depression in the formation base near the Kwaadmechelen locks (Fig. 14a, profile C, arrow 1). The incisive feature cuts through the stiff Boom Clay (OL1 in Fig. 14a) down into the Eocene. Following the drowned valley hypothesis of Figure 4, an ENE continuation of this depression should intersect the survey record made on the nearby Dessel to Kwaadmechelen Canal, but no equally deep incision was recognized at the expected location (Fig. 14a, profile A, arrow 2). This supports the hypothesis of the depression as a closed trough rather than a valley-like incision.

A similar closed depression, though somewhat less deep, was found in a 2004 survey line, oriented west-east near Olmen (Jef Deckers, pers. comm., 2019; Fig. 14b). The survey line crossed the Dessel to Kwaadmechelen Canal at a location where the trough is not at its full depth of $70-80 \mathrm{~m}$, which again allows to infer the closed character of the trough (i.e. its thalweg has a descending part followed by an ascending part). The Olmen trough is offset, with respect to the principal direction, by about $3 \mathrm{~km}$ from the Kwaadmechelen trough (both troughs are incorporated in the basal surface such as depicted in Fig. 5). The profiles show a chaotic to possibly stacked channel fill in the incisions; reflections at the base are relatively stronger.

The interpreted canal seismic profiles also show that the Diest Formation contains internal inclined beds in the fringe area outside the RVG, where the formation thickness of around 100 $\mathrm{m}$ is still sufficient to allow recognition of the internal reflectors. Inclined beds are also prominent in the Noorderkempen, e.g. on seismic lines shot near Baarle-Hertog and Ravels (Jef Deckers, pers. comm., 2019). Figure 14b summarizes the clinoform occurrence and dip. Also the location of basal incisions near Kwaadmechelen is shown.

The organisation of inclined beds allows to identify at least two architectural systems, possibly three, inside the Diest Formation in the area of the canal seismic surveys (Fig. 14b). One is found in the south, between Olmen, Herentals and around Kwaadmechelen. This system is characterized by a clearly erosive base, with localized, several tens of metres deep troughs. Furthermore, at least in an area north of Kwaadmechelen, lowangle (1\%) large-scale inclined surfaces are observed in this system. Possibly, De Batist \& Versteeg's (1998) lower unit "Mi2" in the RVG, which they identified as "Dessel Member", also belongs to the lower system, but this hypothesis needs confirmation. The first system is the lowermost inside the Diest Formation, certainly inside the RVG and most probably also in the Olmen area (Fig. 14a, profile A). This is in agreement with the available biostratigraphic evidence: the samples that allowed biodating belong to the DN8 biozone.

The second system occurs north of the first. It is characterized by large-scale clinoforms that show an overall progradation to NW. They are rather spectacular and well expressed inside the RVG, where aggradational stacks of topsets are also well preserved (De Batist \& Versteeg's (1998) unit "Mi3"). These clinoforms have steeper dips $(5 \%$, locally $8 \%)$ than those found in system 1 . In the Noorderkempen, overall dips of around $2 \%$ are 

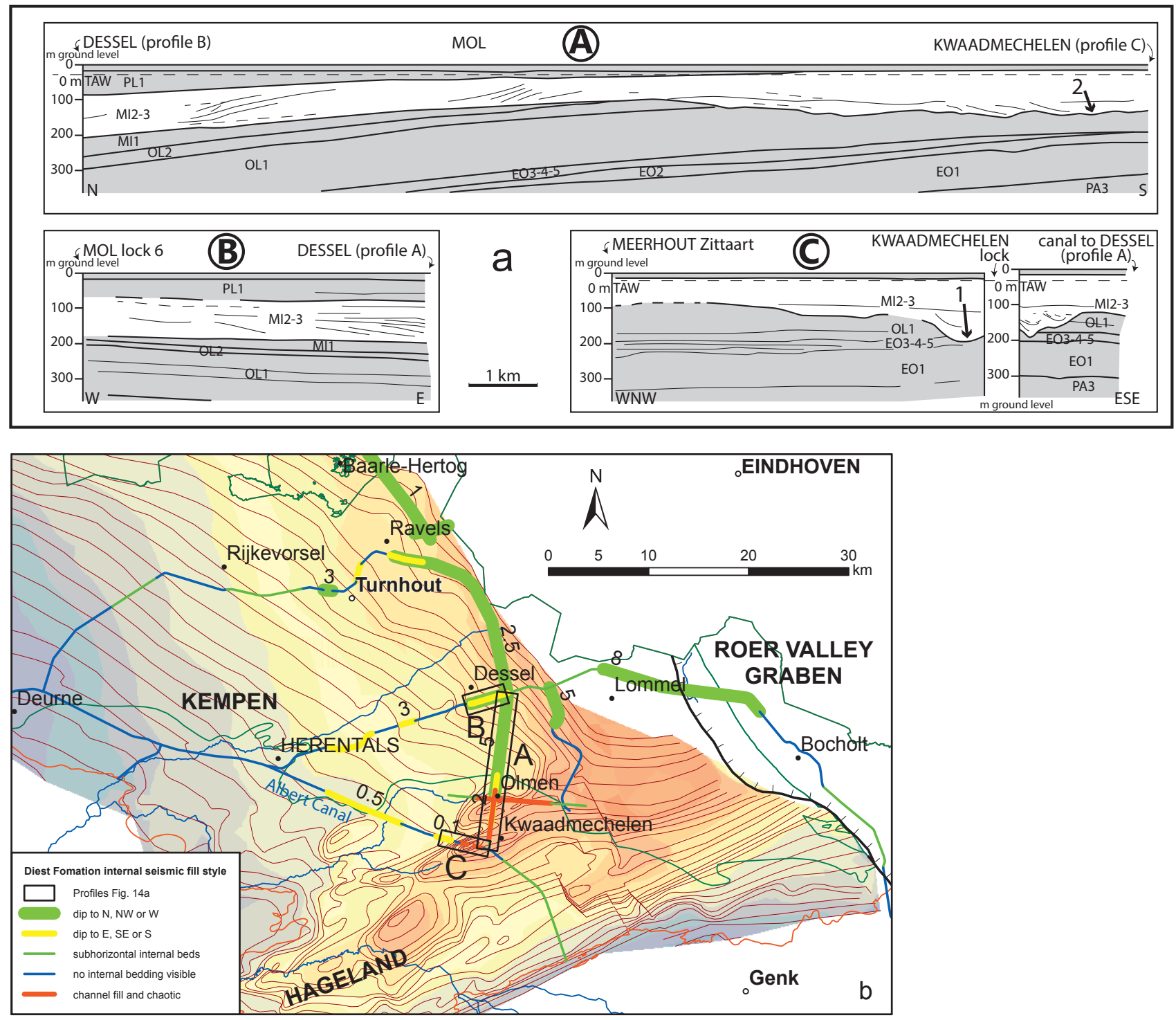

Figure 14. (a) Selected profiles of the "canal survey", based on the data on which De Batist \& Versteeg (1998) is based. For the location of the selected profiles, see Fig. 14b. The Diest Formation ("Mi $\mathrm{Mi}_{2-3}$ ") is highlighted in the profiles. Thin internal horizons (unless dashed) have been re-examined and confirmed by De Batist (pers. comm., 2019). Arrow 1 in profile C shows depression in Diest Formation base. Arrow 2 in profile A indicates where the prolongation along the Hageland Diest sand principal direction of channel 1 in profile C crosses profile A; note that here no deep incision is present. (b) Overview of Diest Formation internal master bedding and clinoforms shown by seismic surveys. Dips, labelled in black, in percent, are real dips in the profile, uncorrected for post-depositional deformation. Where "dip to N, NW or W" and "dip to E, SE or S" overlap, the latter is found in the basal unit. Based on data on which De Batist \& Versteeg (1998) is based, and a few supplementary seismic surveys (Jef Deckers, pers. comm., 2019). Background is coloured Diest Formation thickness model of Fig. 6 and fine dark brown contour lines of Diest Formation base of Fig. 5. The location of the profiles of Fig. 14a is shown in black outlines labelled A, B, C.

observed. The individual clinoforms are laterally extensive inside the seismic profiles and often cross all of the second system. A local unit SW of the line Dessel - Turnhout may be present with clinoforms dipping about 3\% E. It is found below system 2 and it cannot be decided based on the available observations whether it may be part of system 1 or 2 .

The seismic surveys only cover a part of the Diest Formation extent. West of Herentals and Rijkevorsel, and south of Kwaadmechelen, the formation is too close to the surface to allow imaging of any internal structure in the existing surveys. Based on geographic proximity and similar architectural elements evident from outcrops, the Hageland Diest sand correlates with the lower, southern system. Based on the occurrence of samples yielding the DN8 biozone, the Deurne Member might also correlate to the lower system.

The delineation of the architectural systems that emerge from the seismic surveys is at this stage preliminary. New, higher resolution data are needed to construct a clearer image of the large-scale internal structures of the Diest Formation and map the architectural systems.

\subsection{Interpretation}

Seismic system 1 can be identified with the part corresponding to biozone DN8 and the lower sedimentary cycle proposed by Vandenberghe et al. (2014). It covers a complex erosional incision surface, in which it also fills deep, a few kilometres long and a few hundreds of metres wide, trough-shaped depressions. At least locally, near Olmen - Kwaadmechelen, a part of the system north of some deep basal incisions shows an internal lateral progradation to the SE (Fig. 14b).

Seismic system 2 is younger and is correlated with biozones DN9 and DN10 and the upper sedimentary cycle of Vandenberghe et al. (2014). It is a prograding delta deposit. The part around Lommel-Bocholt, inside the RVG, was actively subsiding during deposition, as shown by the preserved topsets. This implies that the sand fraction of the sediment input was trapped in the area of active subsidence and the active delta front.

The sediment front reached the Noorderkempen area only during DN10. The progradation direction suggests the sediment is supplied from or via the SE reach of the RVG by the precursors of Rhine and Meuse. They supplied increasing amounts of clastics 
from the uplifting Rhenish Shield and Alps (Vandenberghe et al., 2014).

\subsection{The transition area}

The Veerle borehole (Fig. 1B) is situated in the transition area of Hageland to Kempen. In this borehole, the Diest Formation is $100 \mathrm{~m}$ thick (4 to $104 \mathrm{~m}$ below the surface), which is larger than in surrounding boreholes because it sits in one of the basal depressions of the formation. The lower part of the Diest Formation at Veerle, below $68 \mathrm{~m}$ depth, is characterized by finegrained sand while the upper part shows medium Hageland Diest sand (Vandenberghe et al., 2014; Verhaegen, 2020, this volume). Only a limited number of analyses have been performed, but the grain-size distribution of one sample at $73 \mathrm{~m}$ depth and the heavy mineral association at 73 and $82 \mathrm{~m}$ match well with samples of the Dessel Member (Verhaegen, 2020, this volume). The latter two samples also revealed a DN 8 zone (Louwye in Vandenberghe et al., 2014). A few cores of this interval are preserved at the repositories of the Geological Survey of Belgium (GSB). They show a depositional structure that differs from the bioturbated Dessel Member. The sand has a chaotic structure, contains throughout a small subpopulation of coarse quartz grains and dispersed small greenish clay lumps. It is interpreted (RH) as a fine-grained, poorly sorted submarine mass flow deposit. This makes it a distinct sedimentary facies of the Dessel Member in this borehole.

\subsection{Synthesis on the regional correlations}

Some deposits were in the past considered part of the Diest Formation. They are now recognized as products of completely different deposition cycles and should be removed from the Diest Formation:

- There is consensus about the Kasterlee Formation, the former diestien supérieur: it is the product of a more recent, uppermost Miocene, shallow marine to peri-marine deposition cycle (Fobe, 1995; Louwye \& De Schepper, 2010; Verhaegen, 2020, this volume; Verhaegen et al., 2020, this volume; Vandenberghe et al., 2020, this volume).

- The Flemish Hills sand, of unknown age somewhere between the latest Eocene and the Pliocene, has a depositional environment that is incompatible with that of the Diest Formation (Houthuys, 2014). Several ages have been proposed, but the matter is not solved yet.

- The "Gruitrode Molen Member" found in outcrop near Opitter can be no part of the Diest Formation as the latter has recently been found at lower levels, in the subsurface of the same area. Houthuys \& Matthijs (2020, this volume) suggest that, together with the "Dorperberg Member, the glauconiferous outcrops are the deposit of a single sedimentary cycle of unknown age, younger than "lower Mol" (Vandenberghe et al., 2020, this volume) and thus definitely younger than the Diest Formation.

The bulk of the Diest Formation sediments in Belgium can be subdivided in two provisional, informal lithostratigraphic units, introduced here, and each associated with a separate depositional cycle: a lower one named "Hageland Diest sand" and an upper one named "Kempen Diest sand".

The Hageland Diest sand groups the Diest Formation of Hageland and the Zuiderkempen, the Central Limburg Diest Sand, the basal part of the Diest Sand inside the RVG, the basal part of the Dessel Member in the Antwerpse Kempen, and probably the Deurne Member. Most units yielded biozone DN8. No dinoflagellates were ever found in Hageland, but geometric continuity suggests membership of the Hageland Diest unit, which implies also a time equivalence. For the same reasons, the fringes of the Diest Formation outcrop in the area between Hageland and Antwerpen should be part of the Hageland Diest sand unit. A rare exposure of the Diest Formation in that area, at Grobbendonk, showed dm-scale cross beds with westward dipping foresets (Vandenberghe et al., 2000). The unit corresponds to the southern and lowermost seismic system introduced above. It largely corresponds to the first separate depositional cycle (Tor1 proposed by Vandenberghe et al., 2014).

The second unit, Kempen Diest sand, contains the Diest Formation deposits associated with the DN9 and DN10 zones of the northern part of the Antwerpse Kempen; deposits pertaining to DN9 have also been identified in the RVG (Maaseik borehole). Using geometric continuity, most of the Diest Sand in the RVG in North-Limburg is part of the Kempen Diest sand. The second unit can be identified with the second seismic system with its large-scale clinoforms dipping to NW. In the central Kempen, the unit probably overlays the northernmost part of the Hageland Diest sand. It largely corresponds to the Tor2 depositional cycle, such as proposed by Vandenberghe et al. (2014). It extends to the NE as the Diessen Formation, which attains 500 m thickness in the centre of the RVG (Munsterman et al., 2020). There, after a depositional hiatus at least spanning the earliest Tortonian, sedimentation resumed in the early Tortonian and continued into the Messinian. Like in the Kempen Diest sand, the Diessen Formation shows an overall coarsening upwards trend from a highly glauconiferous base and a clayey or silty lower part to a fine sandy middle and upper part. The internal architecture shows large-scale clinoforms, downlapping on the MMU surface, dipping about $2^{\circ}$ and prograding from east to west. It is interpreted as a shallow marine pro-deltaic deposit. The top surface, correlated to the LMU, is an erosional truncation; all topsets are missing. There are indications for a subaerial exposure of the top of the Diessen Formation in some boreholes (Munsterman et al., 2020).

The exact areal extent of both units inside the Diest Formation remains to be mapped out. Little is known about the nature of the interface surface of the Kempen Diest sand with, and the lateral or vertical transition to, the Hageland Diest sand.

\section{Sedimentary models of the Diest Formation}

Pre-1960s statements about depositional environment, time of deposition and lateral correlations naturally dealt with the deposit associated with the oldest cycle, the Hageland Diest sand.

For a long time, the Flemish Hills sand was considered to be an integral part of the Diest Formation. Gullentops \& Broothaers (1996) interpreted the unit as a coastal barrier of the Diest Sand. Gullentops (1988) also put forward a marine seaway connection during the deposition of the Diest Sand between the North Sea basin and the Atlantic domain via the English Channel and precursor of the Dover Strait.

Gullentops (1957) proposed an appealing model to explain the peculiar shape, disposition and topography of the Hageland hills, a model that is still often cited today. It was inspired by a shape analogy and a supposed internal depositional structure similarity between the elongated Hageland hills and the present Flemish Banks in the southern North Sea. It claimed that the Hageland hills were the remainder of large-scale, tidal sandbanks (in the sense of tidal current ridges). The model proposed that the marine seaway to the English Channel funnelled the tidal currents, which would have scoured the depressions characterising the erosive base of the formation. At a given stage, a sudden and dramatic drop in sea level would have closed the precursor of the straits of Dover (Gullentops \& Huyghebaert, 1999, p. 201) and exposed the crests of the Hageland sandbanks, allowing limonite cementation, which would protect the crests against subaerial erosion during further uplift of the area. Houthuys (2014) and Houthuys \& Matthijs (2018) however argued that this model is not in agreement with the current knowledge of the palaeogeographic context and the internal structure of tidal current ridges.

\subsection{Hageland Diest sand cycle}

The deposit associated with the oldest cycle, the Hageland Diest sand, is very particular. Its main area of occurrence is an incised basin that cross-cuts the general, regressive strike of the Neogene depositional succession into which it is inserted. The basin is not imposed by a tectonic structure such as a graben. It contains several, well-localized, deep incisions at its base. Some of these even descend tens of metres deep into stiff and consolidated Oligocene Boom clay. Thick stacks of cross-bedding occur throughout the deposit and are, at least in the area where also the base crops out, associated with the incision. Cross bedding can be inserted in, or laterally grade into, finer-grained and strongly bioturbated sand units. In the outcrop area, very thick cross-beds are also found in the middle or near the top of the formation (Fig. 9). Formulating a sedimentary model that accommodates all these observations is a challenging task. Currently, two models aspire to explain the genesis of the Hageland Diest sand. 


\subsubsection{Alternative 1: lateral fill of a confined marine embayment}

Houthuys (2014) argued that continental incision in the time preceding the deposition of the Hageland Diest sand alone cannot explain the complete vertical amount and style of incision observed in the basal surface of the Diest Formation. The local deep incisions and associated very large dunes are thought to be the product of channelized flow, in which the focus of erosion moves to the (E)NE, and is immediately followed by sedimentation (see Fig. 10). He proposed an autocyclic mechanism driven by the confined nature of a marine tidal embayment that was subject to lateral fill. The presence in seismic profiles, just north and west of some of the deep incisions, of large-scale, low-angle clinoforms dipping SE (Fig.14a, profiles A and B), normal to the principal direction (Fig. 14b), supports the hypothesis of a lateral fill process.

Houthuys' (2014) model can be summarized as follows (Fig. 15). During pre-Diest Formation relative low sea-level stand, the emerged land at the SW-side of the RVG marine bay was eroded primarily in and near the course of one or several local rivers, that drained the land surface in a consequent way to the NE. This caused a wide, shallow eroded area whose rate of incision depended on the range of the associated sea-level fluctuation. The model claims that the initial incision created a substantially shallower and uncomplicated basin than the observed complex

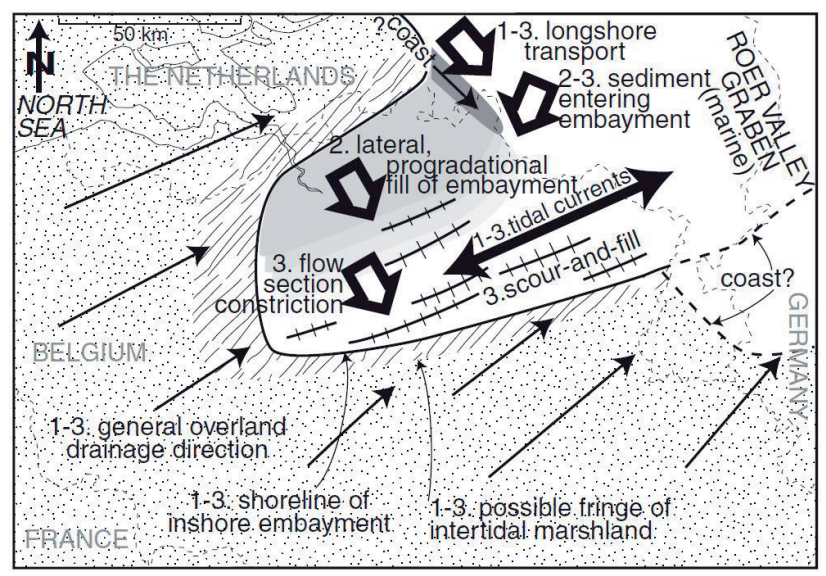

Figure 15. Inferred, generalized palaeogeography during the deposition of the Diest Formation (Houthuys, 2014, fig. 7). Present-day coastline and state boundaries are shown in fine lines for reference. Stages in the palaeogeographic evolution: 1. during rising sea level: drowning of a river mouth area and establishment of a tidal marine embayment; 2 . at high sea level: first stage of filling with lateral progradation from NW to SE; 3. last stages with subtidal flow section constriction and formation of elongate scour-and-fill troughs. Stippled area is emerged at all stages. Note that the precise extent of the embayment and its intertidal fringe is unknown.

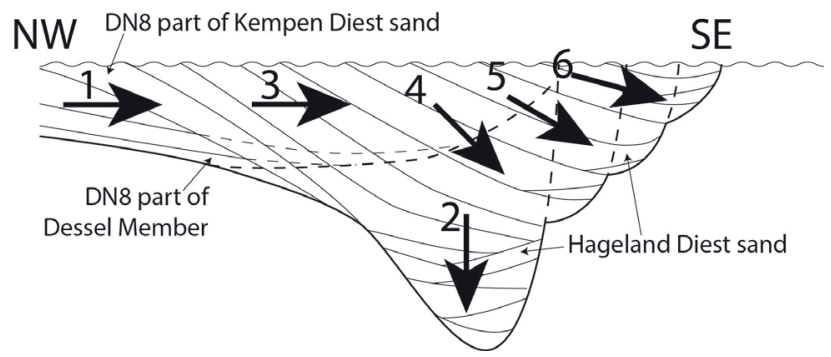

Figure 16. Conceptual sketch providing a likely, but so far still hypothetic sequence of events explaining the observed morphology of the Diest Formation basal surface. The numbers do not refer directly to the stage numbers of Fig. 15 but merely represent successive time steps. Vertical dimension is strongly exaggerated. The lateral progradation, here represented by arrows 1 and 3, actually continues all the time and is the ultimate driving force of the vertical and lateral incision stages $2,4,5$ and 6 . The base of the lateral progradation deposits near arrow 1 extended further to the SE before its intraformational erosion. In the lithostratigraphy, it is known as the DN8 part of the Dessel Member.
Hageland basal incision, that would only be generated at a later stage. At subsequent relative sea-level rise, the river mouth area would be flooded first. The southern North Sea had tides. It is thought that tides were amplified inside the flooded river mouth area, like in some bays and estuaries today. During flooding and transformation of the former river mouth area into a tidal embayment, all fluvial or continental deposits were partly removed, partly reworked into a tidal ravinement surface.

Along the coastline, outside the embayment, longshore transport took place. The sand of this transport path fed into the tidal embayment at the north side. This lateral fill produced the SE-dipping large-scale clinoforms observed in some seismic lines. When this fill proceeded, flow sections in the remaining part of the tidal embayment got progressively narrower. It is further argued that constant amounts of sea water kept entering the embayment, as at high tide, water also flows over the marginal tidal flats and marshes and the earlier sediments inside the embayment. This tidal water volume had to evacuate from the embayment at every low tide through ever smaller flow sections. At the same time, equal amounts of sediment continued to be imported into the embayment. The result is ever narrowing ebb channel sections with strong ebb currents. This stage can be called ebb flow section constriction. The locally reinforced ebb currents are believed to have produced vertical scour that created streamlined, elongated troughs. The vertical scour events had no long life: they were immediately filled by sand derived from the lateral fill. The scour fills show large proportions of ebb-oriented thick cross-beds. Related to the continuing lateral progradation, oversteepened submerged banks incidentally failed and produced breaching turbidity flows or other types of mass deposits, such as observed in the lower part of the Veerle borehole.

The stages of flow constriction are believed to have consisted of successive, similar events differing, depending on local conditions such as the consistence of the substratum, in the degree of vertical and lateral erosion, in the way illustrated by Figure 16. This figure also reveals how the DN8 part of the Dessel Member and any DN8 deposits underneath the Kempen Diest sand need to be an integral part of the Hageland Diest sand system, according to this model. As to the Deurne Member, it has all the sedimentary characteristics of the Hageland Diest sand system: erosive base, lithology, ichnofabric, sedimentary facies including strongly bioturbated fine sand and very thick cross beds which are associated with intraformational erosion. It seems unlikely that it would constitute a separate instance of a same, in itself uncommon, sedimentary system.

The main implications of this model are: (1) the erosion at the base of the Hageland Diest sand is a polygenetic erosion surface, of which the deepest segments and the parts located near the SE side of the basin are intraformational, meaning they developed during the high-stand fill of the Diest marine embayment and locally removed earlier Diest sediment. Only the first stage of erosion is directly related to the MMU. (2) Most of the emplaced sediment was imported from the marine domain; however, during intraformational scour, also underlying older sediments were reworked, which can partly explain the southern signature of the heavy mineral association in the Hageland Diest sand. (3) Inside the Hageland Diest sand, an internal younging direction is present from NW to SE. (4) At the top of the Hageland Diest Sand of the more proximal parts of the basin, near Brussels and Leuven, tens of metres have been truncated, because very thick cross-beds indicative of very large dunes that require deeper water conditions are found also near the top of outcrops. (5) The Hageland Diest sand is internally differentiated in coarser and finer grained units. The elongated bodies of coarser sand were later differentially eroded to cause the present Hageland Hill morphology.

\subsubsection{Alternative 2: two-stage fill}

Verhaegen (2019) proposed an alternative, two-stage fill model of the Hageland Diest sand. This model takes into consideration the fact that the Veerle borehole contains a lower unit of fine-grained glauconiferous sand, attributed to the Dessel Member, covered by an upper unit of coarser, possibly cross-bedded Hageland Diest sand. The heavy minerals of both units show different provenance areas: the Dessel part has a northern provenance, while the coarser upper part displays a southern provenance. 
The difference was shown to be unrelated to differences in grain sizes between both units. This model generalizes both units as two regionally superposed deposits. A pre-formational incision, either by a river, tidal currents or another mechanism, which can be considered as the local expression of the MMU, was followed by sea-level rise and marine transgression, and the deposition of the DN8 part of the Dessel Member, filling the incisions. A later stage of tidal sandbank migration over a relatively flat sea bottom laid down the upper, cross-bedded part of the Hageland Diest sand. The two stages model takes into account the fact that the position of the Hageland hills may be independent of the position of the incisions. Either the final sandbank morphology has been preserved (sensu Gullentops, 1957) or different facies filling the inter-bank depressions were differentially eroded afterwards to give rise to the modern Hageland hill topography.

\subsection{The Kempen Diest sand: a prograding delta front}

The Kempen Diest sand, which is associated with the second cycle, occurs more to the north and shows a clear internal progradational and younging direction to NW. It is interpreted as a single, large marine delta prograding from SE to NW, mostly inside the RVG, but extending also over the SW shoulder of the graben into the Central Kempen and Noorderkempen area. The available biostratigraphic data show that progradation of the delta took a considerable amount of time spanning biozones DN9 and 10 (Deckers \& Louwye, 2020). Active subsidence was taking place during sedimentation, especially inside the RVG, such as indicated by the aggrading and preserved topset structures in the Lommel - Bocholt area, and probably also on the SW shoulder of the RVG in the Noorderkempen (Deckers \& Louwye, 2020), implying depositional water depths well over 100 or $150 \mathrm{~m}$. The actual depositional environment at the delta front is associated with low hydraulic energy. The sedimentary structures observed in cores often show sand homogenized by bioturbation. The gentle, regular offlap style of the delta clinoforms, without tidal bars and channels, seems to imply the absence of tides. Alternatively, the observed geometry may just reflect the deeper marine environment sheltered from strong tidal currents. The seismic coverage does not allow to construct a detailed image of the delta; a model delta would consist of several lobes displaying a range of progradation directions. The delta foreset angle decreases from $8 \%$ inside the Belgian part of the RVG to about $2 \%$ in the more distal Noorderkempen. The overall progradation is driven by sediment input from the SE part of the RVG where, at that time, the mouth area of the Rhine and Meuse rivers was situated (Vandenberghe et al., 2014). Significant influx of clastic material from the uplifting Rhenish Shield created the fluviatile Inden Formation in the Lower Rhine Basin, the lateral equivalent of the Kempen Diest sand. The angular coarse-sand grains found admixed throughout the Kempen Diest sand are attributed to this river input. The significant fraction of weathered glauconite, limonite grains and continental clay minerals are also indicative of a continental provenance. The high percentages of (transported) glauconite are challenging to fit in the delta model.

\section{Discussion}

Despite a similar lithology and an overall coarsening upwards grain-size trend throughout the Diest Formation deposits, most of the evidence gathered in the recent decades supports the thesis formulated by Vandenberghe et al. (2014) that the formation contains the deposits of two different, successive sedimentary sequences. In this paper, we still use the informal names of Hageland Diest sand and Kempen Diest sand to designate the respective associated deposits, as our knowledge about their relative distribution and the location and nature of their interface surface is insufficient. New geophysical surveys are needed to better resolve the structure of the shallow subsurface. They would also help to substantiate a suitable model for the Hageland Diest sand.

The two-stage fill model is attractive because it is a classic layer model, but it struggles to explain the deep incisions at the base. If they are filled valleys, exceptional external conditions such as a large-magnitude tectonic movement or sea-level movement would be needed, for which no independent evidence is found in the region. And it does not explain the incisions at all if they are closed troughs, as such erosion requires highly energetic hydrodynamic events, of which no sedimentary traces are found in the first layer of the model.

The model of lateral fill in a confined embayment was invoked for the first time to explain the incised fill of the Eocene Brussels Sand Formation in central Belgium (Houthuys, 2011). The basinscale internal structure of the Brussels Sand is well known thanks to the study of former large outcrops. There is a strong analogy between the basin shape and characteristics, internal sedimentary structure and facies variations of the Brussels Formation and the Hageland Diest sand (Houthuys, 2014; Houthuys \& Matthijs, 2018). The model explains well the challenging features characterizing the Hageland Diest sand, but definite proof of the validity of the model still awaits a better knowledge of the largescale basin geometry, fill architecture and timing constraints.

Deposits with similar basin shape and dimensions, incision style and fill characteristics are found worldwide and throughout the depositional record. Most models invoked to explain such deposits either involve strong tidal currents in a drowned valley or estuary, or strait-related currents, even while in many cases, there is no clear proof that an associated strait actually existed. The Hageland Diest sand lacks typical tidal estuary characteristics (Houthuys, 2014). One well-studied region where several deposits with stacks of thick cross-beds are indubitably related to marine straits, i.e. Calabria in southern Italy (Longhitano, 2018), has a completely different tectonic and palaeogeographic setting than the Hageland Diest sand.

The second sequence, the Kempen Diest sand, connects over the border to the Diessen Formation in the Dutch sector of the RVG (Munsterman et al., 2020). This would represent a more distal part of the delta found in the SE area of the RVG. The age of deposition of the Diessen Formation corresponds to most of the Tortonian and part of the Messinian, i.e. it correlates to biozones DN8 to DN10 (Munsterman et al., 2020). It is not clear whether the base of the Diessen Formation would correlate to a separate unit functioning as a local equivalent of the Hageland Diest sand, or is incorporated in the prodeltaic marine deposit.

The Kempen Diest sand contains a large volume proportion of reworked glauconite pellets. It is unlikely that older glauconiferous sands in the RVG are the source of these pellets (as was suggested by Vandenberghe et al., 2014; Figs 10 and 11) since the graben was actively subsiding during the upper Miocene. Another source was suggested from the NW. Such provenance is also supported by the glauconite mineralogy of the bulk of the Kempen Diest sand (Adriaens, 2015). However, the question is not settled yet. A source from SE would ensue from the unit's large-scale internal structure. An uplifted and eroding greensand may have been present in the immediate vicinity, such as the slightly older Hageland Diest sand; however, the K-Ar ages are different and it is not clear when uplift of the Hageland area started. Therefore, the actual source remains currently unknown.

\section{Conclusion}

This paper reviews and integrates results of research conducted since the 1960s on the upper Miocene Diest Formation. Sediments occurring in the summit of the Flemish Hills that were previously considered part of the Diest Formation are now omitted from it. Also deposits described as the Gruitrode Molen Member of the Diest Formation, only found in a small area south of Bree in the province of Limburg, can no longer be considered part of the Diest Formation. The main body of Diest Formation Sand in NEBelgium likely consists of the deposits of two separate, sea-level dominated sedimentary cycles.

The lowermost cycle is thought to have deposited the "Hageland Diest sand" (informal name), which is found in the outcrops in Vlaams-Brabant, Limburg, the Zuiderkempen, and the SW-fringe of the Kempen, and probably includes the Deurne Member near the city of Antwerpen and the lower part of the Dessel Member in the central Kempen and in the Roer Valley Graben (RVG). It is interpreted as the fill of an incised large tidal inlet tributary to the southern North Sea bight, which was at that time situated in the Lower Rhine embayment. It was deposited during the early or middle Tortonian (biochron DN8, 11.0-8.8 Ma). The Hageland Diest sand has many features of a marine deposit, yet the confined area of extent and the presence of tens of metres deep incisions at the base, are challenging to explain. New boreholes and 
advanced geophysical exploration could help to clarify the largescale internal structure and the question whether the incisions are drowned valleys or intraformationally formed closed troughs.

The upper cycle is associated with the "Kempen Diest sand" (informal name). It is found in the RVG and the Noorderkempen, most likely partly covering the "Hageland Diest sand", and extends into the adjoining part of The Netherlands as the recently introduced Diessen Formation. It is the deposit of a prograding marine delta, fed from the palaeo-Meuse/Rhine river mouths, though also containing marine lithological components. The deposit is associated with biochrons DN9 and 10, late Tortonian to earliest Messinian (8.8-6.0 Ma). The age becomes progressively younger to the NW. The accommodation space kept increasing during deposition, due to subsidence of the deposition area, especially inside the RVG.

Much remains to be elucidated on the exact areal extent of both units and the nature of the transition between them. Also theories to accommodate the configuration and depositional architecture have not reached consensus. It is hoped that the framework proposed here inspires new exploration and research efforts.

\section{Acknowledgements}

Many thanks to the reviewers Dr Jean-Yves Reynaud and Dr Freek Busschers. Their detailed and constructive remarks greatly helped improving this article.

\section{References}

Adriaens, R., 2015. Neogene and Quaternary clay minerals in the southern North Sea. Unpublished Ph.D. Thesis, KU Leuven, Leuven, 272 p. https://limo.libis.be/primo-explore/fulldisplay?docid=LIRIAS19 $30587 \&$ context=L\&vid=Lirias\&search_scope $=$ Lirias \& tab $=$ default tab\&lang=en_US\&fromSitemap $=1$, accessed 10/06/2020.

Adriaens, R. \& Vandenberghe, N., 2020. Quantitative clay mineralogy as a tool for lithostratigraphy of Neogene Formations in Belgium: a reconnaissance study. Geologica Belgica, 23/3-4, this volume. https://doi.org/10.20341/gb.2020.018

Adriaens, R., Vandenberghe, N. \& Elsen, J., 2014. Natural clay-sized glauconite in the Neogene deposits of the Campine basin (Belgium). Clays and Clay Minererals, 62, 35-52. https://doi.org/10.1346/ ccmn.2014.0620104

Bos, K. \& Gullentops F., 1990. IJzerzandsteen als bouwsteen in en rond het Hageland. Bulletin van de Belgische Vereniging voor Geologie, 99, 131-151.

Bosselaers, M., Herman, J., Hoedemakers, K., Lambert, O., Marquet, R. \& Wouters, K. 2004. Geology and palaeontology of a temporary exposure of the Late Miocene Deurne Sand Member in Antwerpen (N. Belgium). Geologica Belgica, 7, 27-39.

De Batist, M. \& Versteeg, W.H., 1998. Seismic stratigraphy of the Mesozoic and Cenozoic in northern Belgium: main results of a highresolution reflection seismic survey along rivers and canals. Geologie en Mijnbouw, 77, 17-37. https://doi.org/10.1023/A:1003446611678

Deckers, J. \& Louwye, S., 2020. Late Miocene increase in sediment accommodation rates in the southern North Sea Basin. Geological Journal, 55, 728-736. https://doi.org/10.1002/gj.3438

Deckers, J., De Koninck, R., Bos, S., Broothaers, M., Dirix, K., Hambsch, L., Lagrou, D., Lanckacker, T., Matthijs, J., Rombaut, B., Van Baelen, K. \& Van Haren, T., 2019. Geologisch (G3Dv3) en hydrogeologisch (H3D) 3D-lagenmodel van Vlaanderen - versie 3. Studie uitgevoerd in opdracht van het Vlaams Planbureau voor Omgeving (Departement Omgeving) and Vlaamse Milieumaatschappij. VITO-rapport 2018/ RMA/R/1569, 286 p.

De Clercq, H., Janssens, E., Smets, S. \& Verhaert, G., 2014. Diestiaan ijzerzandsteen: van Demergotiek tot restauratieproblematiek. Contributions of symposium "Omgaan met Diestiaan ijzerzandsteengebruik", 19 September 2014. Vlaamse Overheid, Departement Leefmilieu, Natuur en Energie, Brussel, 55 p.

de Heinzelin, J., 1955. Considérations nouvelles sur le Néogène de l'Ouest de 1'Europe. Bulletin de la Société belge de Géologie, 64, $463-476$.

Delvaux, E., 1884. Compte-rendu de l'excursion du 16 août au Musiekberg et au Pottelberg. Annales de la Société Géologique de Belgique, 12, 74-114.
De Meuter, F. \& Laga, P., 1970. Coiling ratios and other variations of Globigerina pachyderma (Ehrenberg, 1861) and the stratigraphic significance in the Neogene deposits of the Antwerpen area, Belgium. Bulletin de la Société belge de Géologie, 79, 175-184.

De Meuter, F. \& Laga, P., 1976. Lithostratigraphy and biostratigraphy based on benthonic foraminifera of the Neogene deposits of Northern Belgium. Bulletin de la Société belge de Géologie, 85, 133-152.

De Meuter, F., Laga, P., Ringelé, A. \& Roose, V., 1966. Compte rendu de l'excursion du samedi 29 octobre 1966, faite à Deurne, près d'Anvers. Bulletin de la Société belge de Géologie, 75, 392-394.

De Meuter, F., Wouters, K. \& Ringelé, D., 1976. Lithostratigraphy of Miocene sediments from temporary outcrops in the Antwerp city area, Pl. Antwerpen $28 \mathrm{~W}$ and Pl. Borgerhout 28 E. Service Géologique de Belgique, Professional Paper, 1976/3, 49 p.

De Nil, K., De Ceukelaire, M. \& Van Damme, M., 2020. A reference dataset for the Neogene lithostratigraphy in Flanders, Belgium. Geologica Belgica, 23/3-4, this volume. https://doi.org/10.20341/ gb.2020.021

de Verteuil, L. \& Norris, G., 1996. Miocene dinoflagellate stratigraphy and systematics of Maryland and Virginia. Micropaleontology, 42, Supplement, 1-172.

Dewaele, L., Amson, E., Lambert, O. \& Louwye, S., 2017. Reappraisal of the extinct seal "Phoca" vitulinoides from the Neogene of the North Sea Basin, with bearing on its geological age, phylogenetic affinities, and locomotion. PeerJ 5:e3316. https://doi.org/10.7717/peerj.3316

Dewalque, G., 1868. Prodrome d'une description géologique de la Belgique. Librairie Polytechnique de Decq, Bruxelles, 442 p.

DOV, 2019. Tertiair geologische kaart. 1/50 000. Databank Ondergrond Vlaanderen, https://www.dov.vlaanderen.be/portaal/?module=ver kenner\&bm $=\mathrm{aa} 8558 \mathrm{c} 8-5 \mathrm{~d} 75-458 \mathrm{f}-\mathrm{b} 235-\mathrm{c} 20 \mathrm{~d} 913 \mathrm{bbda3}, \quad$ accessed 28/12/2019.

DOV, 2020. Basal surface of the combined Berchem/Bolderberg Formation. Databank Ondergrond Vlaanderen. https://www.dov. vlaanderen.be/portaal $/$ module $=$ verkenner $\& \mathrm{bm}=6 \mathrm{c} 8 \mathrm{~b} 6 \mathrm{aad}-75 \mathrm{c} 6$ 443e-b874-b82b8bd15b74, accessed 04/06/2020.

Dreesen, R., De Ceukelaire, M. \& De Koninck, R., 2010. Natuurlijk voorkomen en karakteristieken van inheemse natuursteen in Vlaanderen-Diestiaan ijzerzandsteen in het Hageland. VITO, Mol, internal report commissioned by Flemish Authorities, ALBON, $122 \mathrm{p}$.

Dumont, A., 1839. Rapport sur les travaux de la carte géologique pendant l'année 1839. Bulletins de l'Académie royale des Sciences et BellesLettres de Bruxelles, 6/2, 464-485.

Dumont, A., 1849. Rapport sur la carte géologique du Royaume. Bulletins de l'Académie royale des Sciences, des Lettres et des Beaux-Arts de Belgique, 16, 351-373.

Fobe, B., 1995. Litologie en litostratigrafie van de Formatie van Kasterlee (Plioceen van de Kempen). Natuurwetenschappelijk Tijdschrift, 75, 35-45.

Glibert, M. \& de Heinzelin, J., 1955a. La faune et l'âge miocène supérieur des Sables de Deurne. I Descriptions. Bulletin de 1'Institut royal des Sciences Naturelles de Belgique, 31/71, 27 p.

Glibert, M. \& de Heinzelin, J., 1955b. La faune et l'âge miocène supérieur des Sables de Deurne. II - Conclusions. Bulletin de l'Institut royal des Sciences Naturelles de Belgique, 31/72, 12 p.

Goolaerts, S., De Ceuster, J., Mollen, F., Gijsen, B., Bosselaers, M., Lambert, O., Uchman, A., Van Herck, M., Adriaens, R., Houthuys, R., Louwye, S., Bruneel, Y., Elsen, J. \& Hoedemakers, K., 2020. The upper Miocene Deurne Member of the Diest Formation revisited: unexpected results from the study of a large temporary outcrop near Antwerpen International Airport, Belgium. Geologica Belgica, 23/34, this volume. https://doi.org/10.20341/gb.2020.011

Gulinck, M., 1960. Un gisement de kiezeloolithes à Lichtaart (Campine). Comparaison avec les cailloutis à kiezeloolithes des collines flamandes. Bulletin de la Société belge de Géologie, 69, 191-210.

Gulinck, M., Geets, S. \& Van Voorthuysen, J.H., 1963. Note sur les sondages du Centre Nucléaire à Mol. Bulletin de la Société belge de Géologie, 72, 283-294.

Gullentops, F., 1957. L'origine des collines du Hageland. Bulletin de la Société belge de Géologie, 66, 81-85.

Gullentops, F., 1963. Etude de divers faciès quaternaires et tertiaires dans le Nord et l'Est de la Belgique. Excursion O-P, 6e Congrès International de Sédimentologie 1963, Belgique et Pays-Bas, 20 p. 
Gullentops, F., 1988. Excursion guide for the Neogene. In Herbosch, A. (ed.), IAS 9th European Regional Meeting, Leuven, Belgium, Excursion Guidebook. Belgian Geological Survey, Brussels, 255260.

Gullentops, F. \& Broothaers, L., 1996. De geologische geschiedenis van Vlaanderen. In: Gullentops, F. \& Wouters, L. (eds), Delfstoffen in Vlaanderen. Ministerie van de Vlaamse Gemeenschap, departement EWBL, Brussel, 6-28.

Gullentops, F. \& Huyghebaert, L., 1999. Neogene stratigraphy in the Itter Valley, Roer Valley Graben rim, Belgium. Aardkundige Mededelingen, 9, 143-146.

Hoedemakers, K. \& Dufraing, L., 2015. Elasmobranchii in de ontsluiting aan de luchthaven te Borsbeek (prov. Antwerpen, België). Afzettingen WTKG, 36/1, 12-19.

Hooyberghs, H. \& De Meuter, F., 1972. Biostratigraphy and interregional correlation of the Miocene deposits of northern Belgium based on planktonic Foraminifera; the Oligocene-Miocene boundary on the southern edge of the North Sea Basin. Mededelingen van de Koninklijke Academie voor Wetenschappen, Letteren en Schone Kunsten van België, Klasse der Wetenschappen, 34, 1-47.

Houbolt, J.J.H.C., 1982. A comparison of recent shallow marine tidal sand ridges with Miocene sand ridges in Belgium. In Scrutton, R.A. \& Talwani, M., The Ocean Floor. John Wiley \& Sons, Hoboken (NJ), 69-80.

Houthuys, R., 2011. A sedimentary model of the Brussels Sands, Eocene, Belgium. Geologica Belgica, 14, 55-74.

Houthuys, R., 2014. A reinterpretation of the Neogene emersion of central Belgium based on the sedimentary environment of the Diest Formation and the origin of the drainage pattern. Geologica Belgica, 17, 211-235

Houthuys, R. \& Matthijs, J., 2018. The Hageland hills, legacies of the depositional architecture of the Miocene Diest Sands. In Demoulin, A. (ed.), Landscapes and Landforms of Belgium and Luxembourg. Springer, Cham, 237-252. https://doi.org/10.1007/978-3-319-58239$9 \_14$

Houthuys, R. \& Matthijs, J., 2020. A new interpretation of the Neogene lithostratigraphy and structure of the "Bree Uplift", NE Belgium. Geologica Belgica, 23/3-4, this volume. https://doi.org/10.20341/ gb.2020.020

King, C., Gale, A.S. \& Barry, T.L., 2016. A revised correlation of Tertiary rocks in the British Isles and adjacent areas of NW Europe. Geological Society, London, Special Reports, 27, 1-719. https://doi. org/10.1144/SR27

Labat, S., Gedeon, M., Beerten, K. \& Maes, T., 2011. Dessel-5 borehole: technical aspects and hydrogeological investigations. SCK $• \mathrm{CEC}$, Mol, external report SCK $\cdot C E N-E R-151,39$ p.

Laga, P, 1972. Een fossielhoudende zandsteen in de Zanden van Diest te Olmen (Antwerpse Kempen). Bulletin van de Belgische Vereniging voor Geologie, 81, 251-254.

Laga, P., 1976. Geologische Doorsneden. Archieven Belgische Geologische Dienst. http://collections.naturalsciences.be/sshgeology/geology/profiles-neogeen2020, accessed 04/06/2020.

Laga, P. \& De Meuter, F., 1972. A foraminiferal fauna found in the lower Member of the Diest Formation of borings in the Antwerp Kempen (NE-Belgium). Bulletin de la Société belge de Géologie, 81, 211220.

Laga, P. \& Louwye, S. (coll. Mostaert, F.), 2006. Disused Neogene and Quaternary regional stages from Belgium: Bolderian, Houthalenian, Antwerpian, Diestian, Deurnian, Kasterlian, Kattendijkian, Scaldisian, Poederlian, Merksemian and Flandrian. In Dejonghe, L. (ed.), Current status of chronostratigraphic units named from Belgium and adjacent areas. Geologica Belgica, 9, 215-224.

Laga, P., Louwye, S. \& Geets, S., 2001. Paleogene and Neogene lithostratigraphic units (Belgium). Geologica Belgica, 4, 135-152. https://doi.org/10.20341/gb.2014.050

Leriche, M., 1929. Sur l'ancienne extension des Sables de Berg (Rupélien inférieur). Bulletin de la Société belge de Géologie, 39, 94-98.

Longhitano, S.G., 2018. Between Scylla and Charybdis (part 2): The sedimentary dynamics of the ancient, Early Pleistocene Messina Strait (central Mediterranean) based on its modern analogue. Earth-Science Reviews, 179, 248-286. https://doi.org/10.1016/j. earscirev.2018.01.017
Louwye, S., 2002. Dinoflagellate cyst biostratigraphy of the Upper Miocene Deurne Sands (Diest Formation) of Northern Belgium, southern North Sea Basin. Geological Journal, 37, 55-67. https://doi. org/10.1002/gj. 900

Louwye, S. \& De Schepper, S., 2010. The Miocene-Pliocene hiatus in the southern North Sea Basin (northern Belgium) revealed by dinoflagellate cysts. Geological Magazine, 147, 760-776. https://doi. org/10.1017/S0016756810000191

Louwye, S. \& Laga, P., 2008. Dinoflagellate cyst stratigraphy and palaeoenvironment of the marginal marine Middle and Upper Miocene of the eastern Campine area, northern Belgium (southern North Sea Basin). Geological Journal, 43, 75-94. https://doi. org/10.1002/gj.1103

Louwye, S. \& Vandenberghe, N., 2020. A reappraisal of the dinoflagellate cyst biostratigraphy of the upper Miocene in the Maaseik well 49W0220. Geologica Belgica, 23/3-4, this volume. https://doi. org/10.20341/gb.2020.013

Louwye, S., De Coninck, J. \& Verniers, J., 1999. Dinoflagellate cyst stratigraphy and depositional history of Miocene and Lower Pliocene formations in northern Belgium (southern North Sea Basin). Geologie en Mijnbouw, 78, 31-46. https://doi.org/10.1023/A:1003793300214

Louwye, S., De Schepper, S., Laga, P. \& Vandenberghe, N., 2007. The Upper Miocene of the southern North Sea Basin (northern Belgium): a palaeoenvironmental and stratigraphical reconstruction using dinoflagellate cysts. Geological Magazine, 144, 33-52. https://doi. org/10.1017/S0016756806002627

Matthijs, J., Lanckacker, T., De Koninck, R., Deckers, J., Lagrou, D. \& Broothaers, M., 2013. Geologisch 3D lagenmodel van Vlaanderen en het Brussels Hoofdstedelijk Gewest - versie 2, G3Dv2. Studie uitgevoerd door VITO in opdracht van de Vlaamse overheid, Departement Leefmilieu, Natuur en Energie, Afdeling Land en Bodembescherming, Ondergrond, Natuurlijke Rijkdommen, VITOrapport 2013/R/ETE/43, 21p.

Mourlon, M., 1898. Les dépôts tertiaires de la Campine limbourgeoise Bulletin de la Société belge de Géologie, 12, 45-58.

Mourlon, M., 1904. Compte rendu de l'excursion géologique aux environs de Bruxelles à Ketelberg, Etterbeek, Watermael, Boitsfort, Stockel et Tervueren. Bulletin de la Société belge de Géologie, Mémoires, 19, 267-317.

Munsterman, D.K., ten Veen, J.H., Menkovic, A., Deckers, J., Witmans, N., Verhaegen, J., Kerstholt-Boegehold, S.J., van de Ven, T., \& Busschers, F.S., 2020. An updated and revised stratigraphic framework for the Miocene and earliest Pliocene strata of the Roer Valley Graben and adjacent blocks. Netherlands Journal of Geosciences, 98, e8. https://doi.org/10.1017/njg.2019.10

Nyst, H., 1861. Notice sur une nouvelle espèce de coquille fossile du genre Pecten, trouvée dans le crag noir d'Anvers, ainsi que sur un gisement à echinodermes, bryozoaires et foraminifères. Bulletin de l'Académie royale de Belgique, 2e série, 12, 198-202.

Rasmussen, E.S. \& Dybkjær, K., 2014. Patterns of Cenozoic sediment flux from western Scandinavia: discussion. Basin Research, 26, 338346. https://doi.org/10.1111/bre.12024

Schäfer, A. \& Utescher, T., 2014. Origin, sediment fill, and sequence stratigraphy of the Cenozoic Lower Rhine Basin (Germany) interpreted from well logs. Zeitschrift der Deutschen Gesellschaft für Geowissenschaften, 165, 287-314. https://doi.org/10.1127/18601804/2014/0062

Sels, O., Claes, S. \& Gullentops, F., 2001. Toelichtingen bij de geologische kaart van België, Vlaams Gewest: kaartblad 18 - 10, Maaseik Beverbeek [1/50 000]. Belgische Geologische Dienst en Ministerie van de Vlaamse Gemeenschap, Afdeling Natuurlijke Rijkdommen en Energie, Brussel, 50 p.

Sintubin, M., Sels, O. \& Buffel, P., 2001. Late Tertiary fault activity in the southwestern boundary fault system of the Roer Valley Graben: evidences from the Bree area (NE Belgium). Netherlands Journal of Geosciences / Geologie en Mijnbouw, 80, 69-78. https://doi org/10.1017/S001677460002374X

Tavernier, R. \& de Heinzelin, J., 1962. Introduction au Néogène de la Belgique. Mémoires de la Société belge de Géologie, de Paléonotologie et d'Hydrologie, série in- $8^{\circ}, 6,7-28$.

Utescher, T., Mosbrugger, V. \& Ashraf, A.R., 2002. Facies and paleogeography of the Tertiary of the Lower Rhine Basin sedimentary versus climatic control. Netherlands Journal of Geosciences / Geologie en Mijnbouw, 81, 185-191. https://doi. org/10.1017/S0016774600022423 
Van Adrichem Boogaert, H.A. \& Kouwe, W.F.P., 1993-1997. Breda Formation. Stratigraphic Nomenclature of the Netherlands. https:// www.dinoloket.nl/breda-formation-nuba, accessed 26/09/2018.

Van Calster, P., 1960. Het sedimentatiemilieu van het Diestiaan ten noorden van Leuven. Unpublished licentiaatsthesis Geologie, K.U. Leuven, Leuven, 115 p.

van den Berg, J.H., Martinius, A.W. \& Houthuys, R., 2017. Breachingrelated turbidites in fluvial and estuarine channels: Examples from outcrop and core and implications to reservoir models. Marine and Petroleum Geology, 82, 178-205. https://doi.org/10.1016/j. marpetgeo.2017.02.005

Vandenberghe, N. \& Gullentops, F., 2001. Toelichtingen bij de geologische kaart van België, Vlaams Gewest: kaartblad 32, Leuven [1/50 000]. Belgische Geologische Dienst en Ministerie van de Vlaamse Gemeenschap, Afdeling Natuurlijke Rijkdommen en Energie, Brussel, 77 p.

Vandenberghe, N., Herman, J., Laga, P., Louwye, S., De Schepper, S., Vandenberghe, J., Bohncke, S. \& Konert, M., 2000. The stratigraphic position of a Pliocene tidal clay deposit at Grobbendonk (Antwerp Province, Belgium). Geologica Belgica, 3, 405-417. https://doi. org/10.20341/gb.2014.040

Vandenberghe, N., Laga, P., Louwye, S., Vanhoorne, R., Marquet, R., De Meuter, F., Wouters, K. \& Hagemann, H.W., 2005. Stratigraphic interpretation of the Neogene marine-continental record in the Maaseik well (49W0220) in the Roer Valley Graben, NE Belgium. Memoirs of the Geological Survey of Belgium, 52, $39 \mathrm{p}$.

Vandenberghe, N., Harris, W.B., Wampler, J.M., Houthuys, R., Louwye, S., Adriaens, R., Vos, K., Lanckacker, T., Matthijs, J., Deckers, J., Verhaegen, J., Laga, P., Westerhoff, W. \& Munsterman, D., 2014. The implications of K-Ar glauconite dating of the Diest Formation on the paleogeography of the Upper Miocene in Belgium. Geologica Belgica, 17, 161-174.

Vandenberghe, N., Wouters, L., Schiltz, M., Beerten, K., Berwouts, I., Vos, K., Houthuys, R., Deckers, J., Louwye, S., Laga, P., Verhaegen, J., Adriaens, R. \& Dusar, M., 2020. The Kasterlee Formation and its relation with the Diest and Mol Formations in the Belgian Campine. Geologica Belgica, 23/3-4, this volume, https://doi.org/10.20341/ gb.2020.014

Verhaegen, J., 2019. Quantitative sediment provenance and volumetric reconstruction. Application to the Miocene of the Southern North Sea Basin. Unpublished Ph.D. thesis, KU Leuven, Leuven, 239 p. https://limo.libis.be/primo-explore/fulldisplay?docid=LIRIAS282 $1609 \&$ context $=$ L\&vid=Lirias\&search_scope $=$ Lirias \&tab $=$ default tab\&lang=en_US, accessed 10/06/2020.

Verhaegen, J., 2020. Stratigraphic discriminatory potential of heavy mineral analysis for the Neogene sediments of Belgium. Geologica Belgica, 23/3-4, this volume. https://doi.org/10.20341/gb.2020.003

Verhaegen, J., Adriaens, R., Louwye, S., Vandenberghe, N. \& Vos, K., 2014. Sediment-petrological study supporting the presence of the Kasterlee Formation in the Heist-op-den-Berg and Beerzel hills, southern Antwerp Campine, Belgium. Geologica Belgica, 17, 323332.

Verhaegen, J., Weltje, G.J. \& Munsterman, D., 2019. Workflow for analysis of compositional data in sedimentary petrology: provenance changes in sedimentary basins from spatio-temporal variation in heavy-mineral assemblages. Geological Magazine, 156/7, 11111130. https://doi.org/10.1017/S0016756818000584

Verhaegen, J., Frederickx, L. \& Schiltz, M. 2020. New insights into the lithostratigraphy and paleogeography of the Messinian Kasterlee Formation from the analysis of a temporary outcrop. Geologica Belgica, 23/3-4, this volume. https://doi.org/10.20341/gb.2020.015

Vernes, R.W., Deckers, J., Bakker, M.A.J., Bogemans, F., De Ceukelaire, M., Doornenbal, J.C., den Dulk, M., Dusar, M., Van Haren, T.F.M., Heyvaert, V.M.A., Kiden, P., Kruisselbrink, A.F., Lanckacker, T., Menkovic, A., Meyvis, B., Munsterman, D.K., Reindersma, R., ten Veen, J.H., van de Ven, T.J.M., Walstra, J., Witmans, N., 2018. Geologisch en hydrogeologisch 3D model van het Cenozoïcum van de Belgisch-Nederlandse grensstreek van Midden-Brabant / De Kempen (H3O - De Kempen). TNO, Utrecht, TNO-rapport, TNO 2017 R11261 - VITO 2017/RMA/R/1348, 109 p.

Wong, Th.E., de Lugt, J.R., Kuhlmann, G. \& Overeem, I., 2007. Tertiary, In Wong, Th.E., Batjes, D.A.J. \& de Jager, J. (eds), Geology of the Netherlands. Royal Netherlands Academy of Arts and Sciences, Amsterdam, 151-171.
Wouters, L. \& Schiltz, M., 2012. Overview of field investigations in and around the nuclear site Mol-Dessel. Project near-surface disposal of category A waste at Dessel. NIROND-TR 2011-42E, 139 p.
Manuscript received 28.01.2020, accepted in revised form 11.07.2020, available online 13.09.2020 